\title{
THE ARMS TRADE TREATY REGIME IN INTERNATIONAL INSTITUTIONAL LAW
}

\author{
WILLIAM THOMAS WORSTER*
}

* Lecturer, International Law, The Hague University of Applied Sciences, The Hague, The Netherlands; L.L.M. (Adv.) in Public International Law, cum laude, Leiden University, Faculty of Law, Leiden, The Netherlands; J.D., Chicago-Kent College of Law, Illinois Institute of Technology, Chicago, Illinois; B.A., Modern European History, University of Kansas, Lawrence, Kansas. I am grateful to my research assistant, Marta Andreeva, for her unfailing efforts to find many of the sources herein. The views expressed, and mistakes made here, are all mine. 
TABLE OF CONTENTS

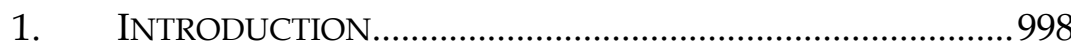

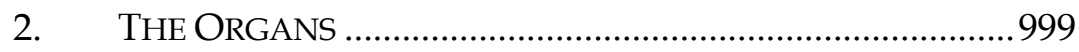

2.1. The Conference of State parties......................................999

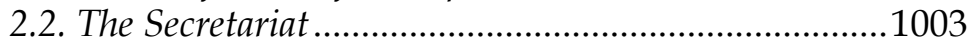

2.3. The Provisional Secretariat...........................................1005

3. INTERNATIONAL LEGAL PERSONALITY ...........................1006

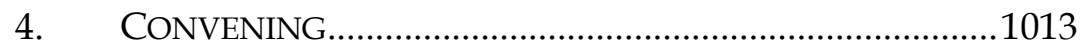

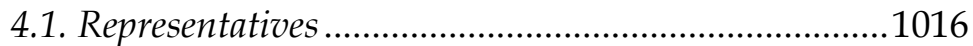

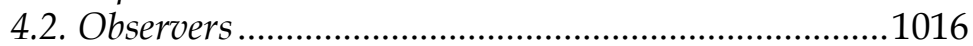

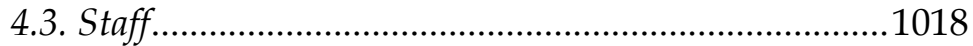

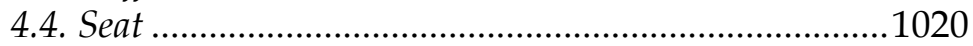

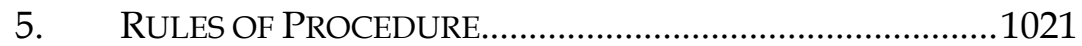

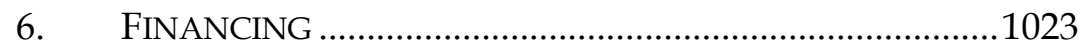

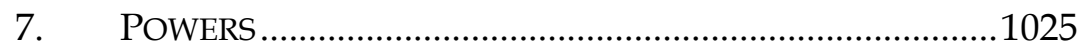

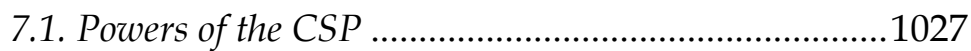

7.1.1. Review implementation of the ATT..................1028

7.1.2. Consider recommendations ...............................1034

7.1.3. Interpretation of the ATT .................................1036

7.1.4. Consider amendments .....................................1038

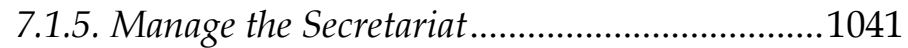

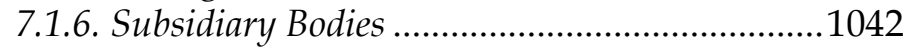

7.1.7. Any Other Function ..........................................1043

7.1.8. Entering into international agreements ...........1044

7.2. Powers of the Secretariat .............................................1046

7.2.1. Distributing documentation..............................1049

7.2.2. Coordinating cooperation ..................................1052

7.2.3. Supporting the CSP .......................................1054

7.2.4. Compliance monitoring .....................................1058

7.2.5. Entering into international agreements ............1058

8. LEGAL EFFECT OF ACTS ................................................1061

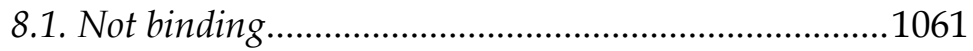

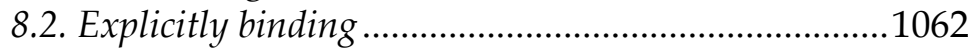

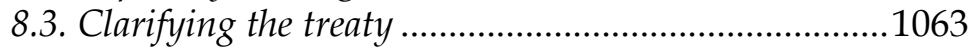

8.4. Establish the criteria for compliance ...........................1064

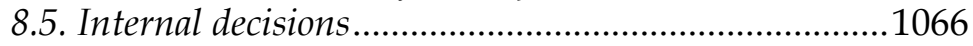

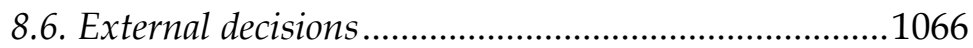

8.7. Subsequent agreement/practice ..................................1067

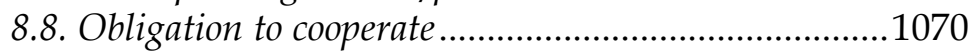

8.9. Customary international law ...................................1072

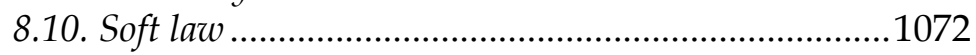


8.11. Countermeasures

1073

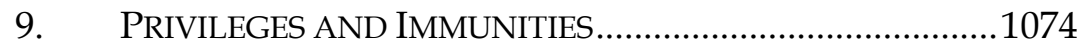

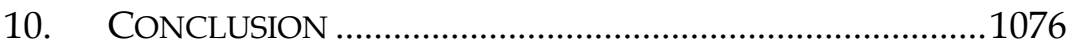




\section{INTRODUCTION}

At the end of 2014, the Arms Trade Treaty ("ATT")1 went into effect, creating new treaty organs that further developed international institutional law regarding quasi-international organizations. On September 25, 2014, eight nation states ratified the ATT, bringing the total number of supporting states to 50 - the minimum number of states needed for the ATT to go into effect. ${ }^{2}$ The state parties to the ATT do not appear to have wanted to create a new international organization to support the treaty, but instead created what is commonly known as a "treaty organ" to do the same task. While the creation of an international organization was once seen as the best solution, nation states are increasingly sensitive to the expense and independence of organizations, and are increasingly attracted to the creation of treaty organs.

Thus, by December 24, 2014, parties to the ATT needed to take steps to create the organs for the treaty regime. In doing so, the state parties to the ATT were able to draw on several decades worth of experience with treaty organs. The state parties created two organs: the Conference of State parties and the Secretariat. These kinds of entities have been with us in some form or another since at least the 1970s.

The emergence of more treaty organs with these entities into the already crowded field of organs containing them shows that creating treaty organs instead of organizations may now be the dominant method for giving effect to bureaucratic regimes. Even though the ATT organs were designed specifically for the start up of the ATT, the initial steps taken show that the ATT organs will likely continue, and buttress crystallizing international practice on treaty organs.

This article reviews those portions of the ATT text that are pertinent to treaty organs that place the new regime into a

\footnotetext{
1 Arms Trade Treaty, adopted as G.A. Res. 67/234B (Apr. 2, 2013) available at http:/ / treaties.un.org/doc/Treaties/2013/04/20130410\%2012-

01\%20PM/Ch_XXVI_08.pdf [hereinafter ATT].

2 See U.N. News Centre, Treaty Regulating Global Arms Trade Set to Enter into Force, http://www.un.org/apps/news/story.asp?NewsID=48856\#.VRf-PjR4p9s (last visited March 29, 2015) ("listing the countries that signed the treaty."). See also Press Release, U.N. Secretary-General, Arms Trade Treaty Enters Force, SecretaryGeneral Announces, Urging Rapid Weapons Regulation through Implementation, Universalization, U.N. Press Release SG/SM/16201 (Sept. 25, 2014) (discussing the enactment of the treaty).
} 
comparative study of similar treaty organs. It will also contribute to the scholarship on treaty organs by functionally applying international institutional law to such entities. This approach is not merely a wish; rather, it represents the current practice regarding these organs, as evidenced through the wide-ranging comparative study of the application of international institutional law.

\section{THE ORGANS}

The ATT creates two treaty organs: the Conference of States Parties ("CSP") 3 and the Secretariat. ${ }^{4}$

\subsection{The Conference of State parties}

The creation of CSPs is a growing trend, and is reflected in an increasing number of treaties. Sometimes these treaty bodies are termed CSP, other times they are referred to as the Conference of Parties ("COP"), "Assembly of States Parties" ("ASP"), "Meeting of Parties" ("MOP") or even "Executive Bureau." 5 This article will draw on a comparative study of other CSPs to analyze how CSPs generally function and theorize how the ATT CSP will potentially function. This comparative study is appropriate because the state parties to the ATT suggested that the CSP model in other treaties inspired them. ${ }^{6}$ With the choice to create a CSP, we can presume that the ATT CSP is intended to function like the other CSPs.

First, we begin with a short background of other CSPs, which are not confined to treaties on specific topics. CSPs have been previously created for arms treaties, 7 but they have also been created

3 ATT, supra note 1, at art. 17.

4 Id. at art. 18.

5 For purposes of this article, all similar organs will be referred to uniformly as CSPs regardless of their specific designation, however, there may be a few instances where this is not the case such as when the organ expressly refers to itself by its correct name.

6 See generally U.N.G.A., Towards an arms trade treaty: establishing common international standards for the import, export and transfer of conventional arms, Report of the Secretary-General, U.N. Doc. A/62/278 (pt. II) (Aug. 17, 2007) [hereinafter U.N.G.A)

7 See generally Convention on Cluster Munitions, May 30, 2008, 2688 U.N.T.S. (No. 47713), art. 11(1) [hereinafter Cluster Munitions Convention]; Convention on 
under, inter alia, human rights treaties. ${ }^{8}$ Where CSPs have truly flourished is within environmental law treaties. The first CSP (though without using the precise term) in an environmental law treaty was in the Ramsar Convention. ${ }^{9}$ The first treaty to use the term "COP" was the Convention on International Trade in Endangered Species of Wild Fauna and Flora ("CITES"). ${ }^{10}$ Subsequently, a great number of environmental law treaties have created CSPs. ${ }^{11}$ This is not to say that the trend to create new international organizations is over-clearly some regulatory conventions do create new international organizations. On the contrary, a new trend to create CSPs runs in parallel to those

the Prohibition of the Use, Stockpiling, Production and Transfer of Anti-Personnel Mines and on their Destruction, Sep. 18, 1997, 2056 U.N.T.S. 211, 36 I.L.M. 1507, arts. 8(2), 10(1) [hereinafter Anti-Personnel Mines Convention]; Protocol on Prohibitions or Restrictions on the Use of Mines, Booby-Traps and Other Devices, May 3, 1996, 35 I.L.M. 1206 (1996); Convention on Prohibitions or Restrictions on the Use of Certain Conventional Weapons Which May Be Deemed to Be Excessively Injurious or to Have Indiscriminate Effects, Oct. 10, 1980, 19 I,L.M. 1523; Treaty on the Non-Proliferation of Nuclear Weapons, July 1, 1968, 729 U.N.T.S. 161 [hereinafter Non-Proliferation Treaty].

8 See generally U.N. Doc. A/58/422, art. 63; Convention on the Rights of Persons with Disabilities, May 3, 2008, 2515 U.N.T.S. 3; Convention against Corruption, Dec. 14, 2005, 2349 U.N.T.S. 41; Convention on the Rights of the Child, Nov. 20, 1989, 1577 U.N.T.S. 3; Convention Against Torture, Dec. 10, 1984, 1465 U.N.T.S. 85. See also Framework Convention on Tobacco Control, May 21, 2003, 2302 U.N.T.S 166.

9 See generally Convention on Wetlands of International Importance, especially as Waterfowl Habitat, Feb. 2, 1971, 996 U.N.T.S. 245 [hereinafter Ramsar Convention].

10 Convention on International Trade in Endangered Species of Wild Fauna and Flora, Mar. 3, 1973, 993 U.N.T.S. 243 [hereinafter CITES].

11 See generally Kyoto Protocol to the United Nations Framework Convention on Climate Change, Dec. 10, 1997, 37 I.L.M. 22 (1998) [hereinafter Kyoto Protocol]; Convention to Combat Desertification in Those Countries Experiencing Serious Drought and/or Desertification, Particularly in Africa, June 17, 1994, 33 I.L.M. 1328 (1994) [hereinafter Desertification Convention]; Convention on Biological Diversity, June 5, 1992, 31 I.L.M. 818 (1992) [hereinafter Biodiversity Convention]; United Nations Framework Convention on Climate Change, May 9, 1992, 31 I.L.M. 849 (1992) [hereinafter UNFCCC]; Convention on the Control of Transboundary Movements of Hazardous Wastes and Their Disposal, Mar. 22, 1989, 28 I.L.M. 657 (1989) [hereinafter Basel Convention]; Montreal Protocol on Substances That Deplete the Ozone Layer, Sep. 19, 1987, 1522 U.N.T.S. 293 [hereinafter Montreal Protocol]; Convention for the Protection of the Ozone Layer, Mar. 22, 1985, 1513 U.N.T.S. 293 [hereinafter Vienna Ozone Convention]; Convention on the Conservation of Migratory Species of Wild Animals, June 23, 1979, 1990 U.N.T.S. 87 [hereinafter Bonn Convention]. 
organizations. ${ }^{12}$ Thus, we have a wide practice crossing various topics.

There are several reasons for the growing popularity of CSPs, but the primary reason for the growing popularity is most likely the increasing treaty compliance and flexibility. One difficulty with many of the older treaties on arms control, and other topics, was the fixed nature of the weapons or other items that were included in the treaty. ${ }^{13}$ As a result, when a new technology was developed, a new diplomatic conference needed to be convened to address the issue. ${ }^{14}$ As a less formal solution, many treaties are now left open-ended with a CSP or similar body having the competence to update the schedule of items prohibited or controlled. ${ }^{15}$

CSPs represent a new approach to the institutional monitoring of treaty compliance. Before CSPs became a feature of some treaties, compliance was measured by mutual good faith, which is normally the case in treaty relations. 16 Over time, practice shifted to creating international organizations to monitor treaty operations. ${ }^{17}$ Within each of these organizations, one organ was designated the COP and it was explicit that the COP organ would be understood to be the principal organ of the organization. ${ }^{18}$

12 See infra notes 17-23.

13 See, e.g., supra note 7.

14 See generally Anti-Personnel Mines Convention, supra note 7.

15 See, e.g., Convention on the Prevention of Marine Pollution by Dumping of Wastes and Other Matter, 1046 UNTS 120, art. 15 (Dec. 29, 1972) [hereinafter London Convention]; Bonn Convention, supra note 11; Basel Convention, supra note 11; CITES, supra note 10; Montreal Protocol, supra note 11.

16 See generally Non-Proliferation Treaty, supra note 7, art. 6.

17 See General Assembly, Meeting of States Signatories of the Comprehensive Nuclear Test-Ban Treaty, Resolution Establishing the Preparatory Commission for the Comprehensive Nuclear Test-Ban Treaty Organization, Doc. No. CTBT/MSS/RES/1 (Nov. 19, 1996), art. 7 [hereinafter Preparatory Commission Resolution] (creating the Preparatory Commission as an international organization pending the entry into force of the Test-Ban Treaty); Comprehensive Nuclear TestBan Treaty, Sep. 10, 1996, U.N. Doc. A/50/1027, 35 ILM 1439, S. Treaty Doc. No. 105, art. 2(B)(24) [hereinafter Test-Ban Treaty]; Convention on the Prohibition of the Development, Production, Stockpiling and Use of Chemical Weapons and on their Destruction, Jan. 13, 1993, 1974 U.N.T.S. 45 [hereinafter Chemical Weapons Convention].

18 See generally Test-Ban Treaty, supra note 17, at art. 2 (B)(24); Chemical Weapons Convention, supra note 17, at art. 8(B)(19); Agreement Establishing the World Trade Organization, Apr. 15, 1994, 1867 U.N.T.S. 154; Convention on International Civil Aviation, Dec. 7, 1944, 15 U.N.T.S. 295. 
However, the practice is now shifting towards establishing CSPs only, without the international organization affiliation, with such organs often termed "treaty organs." 19 These institutions are not merely on-going diplomatic conferences; some are clearly intended to add some normative content. The precise powers of the CSP of the ATT and its international legal personality in comparison with other CSPs is discussed below.

With the emergence of CSPs, two major approaches have been taken. The primary trend is to house the CSP in a secretariat of an existing international organization where the institutional purposes are related. ${ }^{20}$ Another approach is to delegate CSP-like duties to another organization entirely. ${ }^{21}$ One experiment was to set up the treaty body as a subsidiary organ of another international organ rather than as an agency.22

The ATT takes an alternate approach, which is to create a free standing CSP, not housed in, or otherwise linked to, an existing organization. This approach is not without precedent. ${ }^{23}$

19 See HENRY G. SCHERMERS \& NEILS M. BLOKKER, INTERNATIONAL INSTITUTIONAL LAW §§ 386-87 (4th ed. 2003) (defining "treaty organs"). For examples of CSPs created on the basis of treaties, see COP of the UNFCCC; CMP Conference of the Parties serving as the meeting of the Parties to the Kyoto Protocol; Conference of the Ramsar Convention.

20 See generally International Convention on Oil Pollution Preparedness, Response and Co-operation, Nov. 30, 1991, 30 I.L.M. 733; International Atomic Energy Agency, Conventions on Early Notification of a Nuclear Accident and on Assistance in the Case of a Nuclear Accident, Sep. 26, 1986, 25 I.L.M. 1370, 25 I.L.M. 1377 (1986); International Convention for the Prevention of Pollution from Ships, Nov. 2, 1973, 12 I.L.M. 1319 (1973); International Convention for the Prevention of Pollution of the Sea by Oil, May 12, 1954, 327 U.N.T.S. 3; International Plant Protection Convention, Dec. 6, 1951, 150 U.N.T.S. 67.

21 See generally Central African Convention for the Control of Small Arms and Light Weapons, their Ammunition and all Parts and Components that can be used for their Manufacture, Repair and Assembly, Apr. 30, 2010, art. 29.

22 See, e.g., G.A. Res. 2997 (XXVII), U.N. GAOR, 27th Sess., Supp. No. 30, U.N. Doc. A/8730 at 43, (Dec. 15, 1972) (establishing United Nations Environment Program ("UNEP") as a subsidiary organ of the U.N.G.A.).

23 See generally Convention on Nature Protection and Wildlife Preservation in the Western Hemisphere, Oct. 12, 1940, 161 U.N.T.S. 193; African Convention on the Conservation of Nature and Natural Resources, Sep. 15, 1968, 1001 U.N.T.S. 3. 


\subsection{The Secretariat}

In addition to the CSP, the ATT also creates a Secretariat organ. ${ }^{24}$ The creation of a Secretariat organ is another feature increasingly typical in various agreements; especially environmental law treaties and some arms control treaties. ${ }^{25}$ However, this is by no means universal-many human rights treaties and arms control treaties have no secretariat. ${ }^{26}$

In addition to a CSP, a Secretariat is a usual organ created to support the CSP, the States Parties, and treaty regime itself. While a Secretariat (or Secretariat function) is always an organ of any international organization, they are also created to support a regime even where no formal international organization is created. ${ }^{27}$ Often, a treaty creates the Secretariat. ${ }^{28}$ But, in other cases, it is established by decision of the CSP,29 or by provisionally establishing a Secretariat, with the CSP entrusted to make the body permanent. ${ }^{30}$ Even where not initially created by the treaty itself, a Secretariat is often created by the state parties later to give administrative support to the CSP. ${ }^{31}$

Also, similar to the CSP, Secretariats are sometimes placed within an existing international organization. ${ }^{32}$ Although, in at least

24 See ATT, supra note 1, at art 18 (establishing a Secretariat).

25 See infra notes 26-32.

26 See Non-Proliferation Treaty, supra note 7, at art. 16; infra note 33 (no secretariat).

27 See, e.g., CITES, supra note 10, at art. XII; Bonn Convention, supra note 11, at art. IX.

28 See generally CITES, supra note 10, at art. XII(1).

29 See, e.g., Convention on the Prohibition of the Development, Production, and Stockpiling of Bacteriological and Toxin Weapons and Their Destruction, Apr. 10, 1972, 1015 U.N.T.S. 163 (discussing state parties created the Implementation Support Unit in 2006).

30 For examples of treaties that had provisional secretariats, see Vienna Ozone Convention, supra note 11, art. 7(2); Biodiversity Convention, supra note 11, at art. 24(2); UNFCCC, supra note 11, at art. 8(3); Montreal Protocol, supra note 11.

31 See, e.g., Preparatory Commission Resolution, supra note 17 (establishing secretariat later).

32 See, e.g., UNFCCC, supra note 11 (UNFCCC Secretariat within the United Nations Secretariat); CITES, supra note 10 (Secretariat within the UNEP Secretariat); London Convention, supra note 15 (London Convention Secretariat within the International Maritime Organization (IMO) Secretariat). See also Rotterdam Convention on Prior Informed Consent, Sep. 10, 1998, 2244 UNTS 337, art. 19(3) (Secretariat housed jointly in the UNEP and Food and Agriculture Organization Secretariats). 
one case, a non-governmental organization ("NGO") provided the administrative structure. ${ }^{33}$ Some treaty regimes dispense with a Secretariat entirely, and simply delegate those functions to an existing organization. ${ }^{34}$ The usual reason for housing the Secretariat in an existing organization is to benefit from the existing organization's infrastructure, management, prestige, and perhaps even subject specific knowledge, avoiding additional costs. A general caution, however, is that the Secretariat of the treaty regime may not, by integrating into another Secretariat, avoid express limitations on its actions as prescribed in the treaty. ${ }^{35}$ From time to time, there may be a struggle for control of the Secretariat between the hosting organization and the treaty regime. To avoid such conflicts, the CSP and hosting organization usually conclude in an agreement on the precise scope of control. ${ }^{36}$

Turning to the ATT in particular, the treaty merely creates the organ and does not provide any guidance on whether it should be hosted or affiliated with an existing international organization. ${ }^{37}$ During the negotiations, two states expressed the view that the ATT Secretariat should be housed within the United Nations. ${ }^{38}$ Because

33 See The Ramsar Secretariat, RAMSAR, available at http:/ / www.ramsar.org/ the-ramsar-secretariat (providing that the Ramsar Convention Secretariat is housed within the International Union for the Conservation of Nature administration).

34 See, e.g., Non-Proliferation Treaty, Delegation to the International Atomic Energy Agency (IAEA), IAEA Information Circular No. INFCIRC/810 (Dec. 9, 2010) (reporting on the Dec, 32010 note verbale from Iran transmitting information on implementation of the NPT Safeguards Agreement). Also note the unusual situation of the Anti-Personnel Mines Convention involving the Advisory Service on International Humanitarian Law of the International Committee of the Red Cross.

35 See generally Vienna Ozone Convention, supra note 11, at art. 7(2); SCHERMERS \& BLOKKER, supra note 19, at § 33; Framework Convention on Climate Change, Administrative and Financial Matters Institutional Linkage of the Convention Secretariat to the United Nations, 10th Sess., 1 - 5, 7-8, 10, U.N. Doc. FCCC/SBI/1999/7 (Apr. 16, 1999).

36 For examples of control defining agreements see Letter to the President of the Climate Change COP from the Special Adviser to the Secretary-General (Apr. 5, 1995), U.N. Doc. FCCC/CP/1995/5/Add.4, annex; U.N.E.P., The Relationship between the Executive Director of UNEP and the Conventions Regarding the Administration of Their Secretariats, Fourth Meeting on Coordination of Secretariats of Environmental Conventions, U.N. Doc. UNEP/DEP/Coord.4/3/COR.1 1-7, pp 2, 3 (Jan. 4, 1996).

37 See generally ATT, supra note 1 , at art 17.

38 See U.N. Conference on the Arms Trade Treaty, Compilations of views on the elements of an arms trade treaty: Background document prepared by the Secretariat, U.N. Doc. A/CONF.217/ 2 (May 10, 2012) (response of Poland, sec. VII, Apr. 4, 2012) [hereinafter U.N. Secretariat, Compilations of views, May 14,2012]; See also 
the final version of the ATT does not include terms on hosting, we might initially expect a Secretariat to be a freestanding body. However, at the recent preparatory meetings in Mexico City for the first CSP ("CSP1"), the U.N. Office for Disarmament Affairs ("UNODA") was suggested as the specific host. 39 This decision has not yet been finalized as there are lingering concerns that housing the ATT Secretariat within the UNODA would give the universal membership of the U.N. a degree of control over the ATT treaty regime which does not have universal membership. ${ }^{40}$

\subsection{The Provisional Secretariat}

One of the options mentioned above that was adopted in case of the ATT, is the creation of a "provisional Secretariat" that will only convene CSP1 within one year of the entry into force of the ATT, at which time the CSP will need to create a permanent Secretariat. ${ }^{41}$

This practice of creating a provisional Secretariat in the treaty (or sometimes by decision of the CSP) is typical for the startup of the treaty regime operations; ${ }^{42}$ however, an alternative is to entrust the start-up of operations to one state in particular pro tempore. 43

The CSP will assume supervision of the Secretariat at CSP1 and, thereafter, the then permanent Secretariat will convene the annual meeting. ${ }^{44}$ In the negotiations on the ATT, Ukraine proposed that only a temporary Secretariat be established and that a permanent

U.N.G.A., Towards an arms trade treaty, 2007, supra note 6, para. 28 (describing the response of Argentina).

39 See S. Bauer, P. Beijer \& M. Bromley, The Arms Trade Treaty: Challenges for the First Conference of States Parties, SIPRI INSIGHT ON PEACE AND SECURITY NO. 2014/2 (2 Sep. 2014) [hereinafter Bauer, Beijer \& Bromley].

40 Id.

41 ATT, supra note 1, at art. 18(1).

42 For examples of provisional secretariats, see Vienna Ozone Convention, supra note 11, at art. 7(2); Biodiversity Convention, supra note 11, at art. 24(2); UNFCCC, supra note 11, at art. 8(3); Montreal Protocol, supra note 11; CITES, supra note 10 , at art. XII(1).

43 See, e.g., Inter-American Convention Against the Illicit Manufacturing of and Trafficking in Firearms, Ammunition, Explosives, and Other Related Materials, Nov. 14, 1997, OAS Res. A/53/78, annex, art. XXI(5) reprinted at 22 U.N. DISARMAMENT YB, app. III (1997) [hereinafter Inter-American Trafficking Convention] (designating a host State Party for each regular meeting as the Secretariat pro tempore of the committee until the next meeting).

44 ATT, supra note 1 , at art 17(1). 
one should be set up only if necessary. ${ }^{45}$ Currently the preparatory meetings for CSP1 are discussing the structure of the provisional Secretariat, considering three proposals that envision either housing provisional organ in the U.N. Development Programme ("UNDP") or UNODA, or perhaps permitting Mexico to serve as the provisional body pro tempore. ${ }^{46}$ At the Mexico City preparatory consultations, the state parties agreed at least to assign Mexico the task of producing working papers on the Secretariat, rules of procedure, and the funding model for the next preparatory meeting prior to CSP1. ${ }^{47}$

\section{INTERNATIONAL LEGAL PERSONALITY}

Especially in cases where the treaty body is administratively independent of any other institution, we can wonder whether the CSP (or treaty regime generally) is now an international organization in its own right. No CSP in any of the treaties in this study is expressly designated as an international organization. In the few cases cited above where a CSP was created within an international organization, it was clearly the organization that acquired personality, not the organ on its own.

However, express designation as an international legal person is not necessary, and we can find personality implicitly. 48

Unfortunately, there is no fixed definition of an international organization. The International Law Commission ("ILC"), although historically not agreeing to a definition, ${ }^{49}$ agreed to a definition in

45 See UNGA, Report of the Secretary-General, Towards an arms trade treaty: establishing common international standards for the import, export and transfer of conventional arms, U.N. Doc. A/62/278/Add.4, Add. para. 19 (Feb. 15, 2008) (stating the response of Ukraine on Feb. 12, 2008). See also U.N.G.A., supra note 6, para. 27 (stating the response of Bosnia and Herzegovina on Apr. 30, 2007 in considering a semi-permanent organ); id. at para. 11 (stating the response of Costa Rica on Apr. 27,2007 in considering a semi-permanent organ); $i d$. at para. 26 (stating the response of the U.K. in considering a semi-permanent organ).

46 Bauer, Beijer \& Bromley, supra note 39 , at 3.

$47 \quad I d$.

48 See N.D. White, The LAW of International Organizations 27 (1997) (describing methods to determine the personality of a treaty).

49 See, e.g., Summary Record of the Meetings of the Thirty-Seventh Session 6 May26 July 1985, YB INT'L L. COMM'N, U.N. Doc. A/CN.4/SER.A/1985, 105-7 (1985) (refusing to agree on a definition). 
2003, though only in the context of the law of responsibility. ${ }^{50}$ The ILC draft articles state that an "international organization" is "an organizations established by a treaty or other international instrument governed by international law and possessing its own international legal personality." 51 Schermers and Blokker found that international organizations are "forms of cooperation founded on an international agreement creating at least one organ with a will of its own, established under international law." 52 This slight difference of opinion, however, should not distract us from the underlying understanding that organizations only have personality when personality is granted to them, though that grant can be implied. ${ }^{53}$

Based on these various definitions, there is some debate over the legal personality and nature of CSPs and similar bodies. Churchill and Ulfstein have argued that CSPs are, in essence, international organizations and that the principles of international institutional law should apply to them. ${ }^{54}$ The U.N. Office of Legal Affairs ("UNOLA") appears to agree. 55 In 1993, the UNOLA concluded that the UNFCCC established "an international entity/organization with its own separate legal personality, statement of principles,

50 See U.N., 55th Sess., Report of the Int'l L. Comm'n, U.N. Doc. A/58/10, at 38 (2003) (" [A]n organization established by a treaty or other international instrument governed by international law and possessing its own international legal personality.").

51 Id.

52 SCHERMERS \& BLOKKER, supra note 19, at § 33. See also C.F. AMERASINGHE, PRINCIPLES OF THE INSTITUTIONAL LAW OF INTERNATIONAL ORGANIZATIONS 44-48 (1996) (providing how a treaties particular object and purpose assist in its interpretaton).

53 See, e.g., Reparation for Injuries Suffered in the Service of the United Nations: Adv. Op., of April 11th, 1949, 1949 I.C.J. Reps. 174, 178-9 (1949)( noting to answer a "question, which is not settled by the actual terms of the Charter, we must consider what characteristics it was intended thereby to give to the Organization"). But see F. Seyersted, Objective International Personality of Intergovernmental Organizations, 34 NORDISK TIDSSKRIFT FOR INT'L RET. 1-112 (1964) (arguing that when an organ is created with a will of its own, then an international organization exists).

54 R. Churchill \& G. Ulfstein, Autonomous Institutional Arrangements in Multilateral Environmental Agreements: A Little-Noticed Phenomenon in International Law, 94 AM. J. INT'L L. 623, 625, 631-43, 655, 658 (2000).

55 See UNOLA, Arrangements for the Implementation of the Provisions of Article 11 of the United Nations Framework Convention on Climate Change concerning the Financial Mechanism - Legal Capacity of the Conference of the Parties to the Convention and the Global Environment Facility to Enter into an Agreement or Other Arrangement with Third Parties and the Legal Nature of Such Agreement or Arrangement (Nov. 4, 1993), 1993 U.N. Jurid. YB 427, 428-9, para. 4 [hereinafter UNOLA, Arrangements for Implementation 1993] (agreeing with Churchill and Ulfstein). 
organs and a supportive structure in the form of a Secretariat ... ."56 Because the ATT is also established with its own statement of principles, organs, and supportive secretariat, we can apply the UNOLA's reasoning to the ATT. Furthermore, CSPs have been held to be able to grant a treaty secretariat international legal personality on its own initiative and by its own decision. ${ }^{57}$

Whether the ATT creates an international organization has multiple effects, especially in the field of interpretation of the treaty. Interpretation has an impact both on the internal institutional organization of the treaty body and on the kinds of external relations and powers the organ can exercise, as well as their legal effects. ${ }^{58}$ An important result of considering the ATT as creating an international organization is that the doctrine of implied powers, ultra vires, and the "constitutional" interpretation of the constitutive instrument apply. ${ }^{59}$ Furthermore, entities governed by international institutional law can generally influence the interpretation of the treaty themselves through their institutional practice.60 Other considerations would include the implied power to expel a member state from the institution for behavior that is non-conductive to the treaty, but not amounting to a material breach under the Vienna Convention on the Law of Treaties (VCLT). ${ }^{61}$ If, however, principles of international institutional law do not apply to these entities, then the normal rules of treaties apply (the treaty could be considered "self-contained"). ${ }^{62}$

$56 \quad I d$.

57 FCCC, Institutional and Budgetary Matters: Arrangements for Relocation of the Convention Secretariat to Bonn, U.N. Doc. FCCC/SBI/1996/7, 7, available at http://ccsr.aori.u-tokyo.ac.jp/old/unfccc4/lists/list_823.html [hereinafter FCCC, Arrangements for Relocation 1996].

58 See infra notes 44-48 and accompanying text.

59 For examples of international doctrines with implied powers, see U.N. Administrative Tribunal ICJ, Legality of the Use by a State of Nuclear Weapons in Armed Conflict, Judgment, 1996 I.C.J. 66, 79, ๆ 25 (1996); U.N. Administrative Tribunal ICJ, Effect of Awards of Compensation Made, Advisory Opinion of 1954, I.C.J. 47, 53 (1954).

60 See, e.g., U.N. Security Council, Legal Consequences for States of the Continued Presence of South Africa in Namibia (South West Africa), Notwithstanding Security Council Resolution 276 (1970), Advanced Opinion, 1971 I.C.J. 16 (1970) (stating Namibia's advanced opinion).

61 Vienna Convention on the Law of Treaties, May 23, 1969, 1155 UNTS 331 art. 60(2) [hereinafter VCLT]. (1980).

62 U.S. Dipl. \& Cons. Staff in Tehran (U.S. v. Iran), Judgment, I.C.J. 3, 39-41 
Certainly, the ATT CSP is established by a form of cooperation, for example an international agreement under international law. ${ }^{63}$ The ATT CSP has a will of its own, as no state or international organization can instruct it. ${ }^{64}$ However, at least one state specifically intended not to create a new international organization. ${ }^{65}$ While this one statement is not determinative, it does show that there was no unanimous intention to create an international organization.

Some authors have taken a middle ground on CSPs. Schermers and Blokker conclude that these kinds of entities are "intermediate forms between independent organizations and organs of organizations." 66 Because some treaty organs often have no secretariat and no legal personality, the International Law Association concluded that they were "incomplete international organizations." 67 Indeed, this conclusion is the best view, but it must be conditioned on the fact that different CSPs are structured differently with varying limitations on their independence, and given that they are at least partly international organizations, it is difficult to know which part(s) of international institutional law apply. Other CSPs have ranged in their independent will from ones that were very independent to those that carefully limited themselves to the intent of the parties. ${ }^{6}$

63 The ATT is a treaty under the Vienna Convention on the Law of Treaties. See generally ATT, supra note 1; VCLT, supra note 61.

64 F. Seyersted, Objective International Personality of Intergovernmental Organizations, 34 NORDISK TIDSSKRIFT FOR INT'L RET, 47 (1964) (arguing that "will" means it is not instructed by any single state).

65 See, e.g., U.S. Dep't St., Arms Trade Treaty: United States Signs Arms Trade Treaty on September 25, 2013, available at http://www.state.gov/t/isn/ armstradetreaty/index.htm [hereinafter USDOS, U.S. Signs ATT] ("Key U.S. Redlines in the Negotiations ... There will be no mandate for an international body to enforce an ATT." ... "Parameters" ... "No new international organization should be created to enforce an ATT. Exports will ultimately be a national decision.").

66 SCHERMERS \& BLOKKER, supra note 19, at §§ 44, 386-387.

67 Committee on Accountability of International Organizations, First Report, INTL L. ASSOC., 5 (Feb. 1998) [hereinafter ILA First report].

68 See generally B. Siebenhüner, The Biodiversity Secretariat: Lean Shark in Troubled Waters, F. BIERMAN \& B. SiEBENHÜNER EDS., MANAGERS OF GLOBAL CHANGE: THE INFLUENCE OF INTERNATIONAL ENVIRONMENTAL BUREAUCRACIES 265, 284 (2009); S. Bauer, The Desertification Secretariat: A Castle Made of Sand, F. BIERMAN \& B. SIEBENHÜNER EDS., MANAGERS OF GLOBAL CHANGE: THE INFLUENCE OF INTERNATIONAL ENVIRONMENTAL BUREAUCRACIES 293, 300 (2009); P-O Busch, The Climate Secretariat: Making a Living in a Straitjacket, MANAGERS OF GLOBAL CHANGE: THE INFLUENCE OF INTERNATIONAL ENVIRONMENTAL BUREAUCRACIES 245, 261. 
Turning specifically to the ATT CSP, of course it will remain to be seen whether the ATT CSP takes a liberal or conservative interpretation of the organ's nature, but experience with other bodies suggests an approach somewhere in between those two extremes. While some states expressed views on their vision for the ATT CSP, most states did not. ${ }^{69}$ Thus, the CSP, much like other CSPs, appears to be an international treaty-based institution whose membership appears to deny it full international legal personality. The arms control treaties, however, are generally convened by the U.N. Secretary-General and the U.N. Secretariat functions as the treaty secretariat. ${ }^{70}$ These bodies also do not generally have subsidiary bodies. ${ }^{71}$ This stands in contrast to the ATT, which has its own secretariat and its own mechanism for convening, and the parties report directly to it. ${ }^{72}$ What also remains unclear about the CSP of the ATT is the degree to which it develops normative content. Most other arms control treaties are limited to considering amendments to the treaty, but which have to be adopted at a separate diplomatic conference. ${ }^{73}$ The ATT CSP also has this process of considering amendment for adoption at a review conference, but it has additional functions regarding review of implementation, which suggests that it resembles one of the environmental law CSPs more than a classic arms control CSP. ${ }^{74}$ In addition, the arms control treaties that go farther than mere diplomatic conferences tend to

69 See, e.g., UNGA, Report by the Secretary-General, Towards an arms trade treaty: establishing common international standards for the import, export and transfer of conventional arms, UNGA 62d sess. U.N. Doc. A/62/278, pt. II, (Aug. 17, 2011) [hereinafter UNGA, Towards an arms trade treaty, 2011] (stating the response of Switzerland, June 2, 2011 where Switzerland viewed the CSP as acting as an "information broker" to collate and analyze information about the treaty).

70 See, e.g., Anti-Personnel Land Mine Convention, supra note 7, at art. 8; UNODA, Anti-Personnel Mine Ban Convention, available at http://www.un.org/ disarmament/convarms/landmines/article7/ (functioning as the treaty secretariat).

71 Anti-Personnel Land Mine Convention Implementation Support Unit, available at http://www.apminebanconvention.org/implementation-supportunit/activities/overview/.

72 ATT, supra note 1, at art. 17(3)(a). See also id., at art. 5(4), 11(6), 13(1), 13(2), 13(3).

73 Test-Ban Treaty, supra note 17, at art. II(B)(16), (17).

74 See, e.g., CITES, supra note 10, at art. XI(3); Bonn Convention, supra note 11, at art. VII(5); Basel Convention, supra note 11, at art. 15(5); UNFCCC, supra note 11, at art. 7(2)(e-g); Biodiversity Convention, supra note 10, at art. 23(4) (comparing ATT CSP to environmental law CSPs). 
establish true international organizations..$^{75}$ Because the ATT did not go so far, then it must be intended to fall into the middle ground between international organization and diplomatic conference, again, suggesting the model developed for environmental law treaties.

Clearly the ATT CSP is intended to be more formal than an ad hoc diplomatic conference, yet less formal than a true international organization. Based on the practice applied to other CSPs to date, the author will apply principles of international institutional law only to the degree to which the ATT CSP and its Secretariat function as international institutions. ${ }^{76}$ It appears that States Parties do intend for at least some minimal aspects of CSPs to function similarly. ${ }^{77}$ Thus, for example, when the CSP acts, especially when interpreting the ATT, we might presume that it acts intra vires. In this respect, ATT article $17(4)(\mathrm{g})$ ("[p]erform any other function consistent with [the ATT]") is important in conjunction with article $17(4)(d)$ (" [c]onsider issues arising from the interpretation of [the ATT]") in that it appears to provide the CSP with considerable flexibility in how it views its own tasks. We might also view the CSP as having a role in reviewing subsequent membership as per the VCLT, especially if new States Parties wish to enter reservations to the ATT. Therefore, this article will apply general principles of international institutional law where the CSP more closely resembles a normal international institution, but will more heavily rely on the law of treaties where the CSP is more unique.

In addition, or in the alternative, we can wonder whether the ATT Secretariat would enjoy its own international legal personality distinct from the CSP. It is not unheard of for a secretariat of the treaty regime to have international personality. This grant can come

75 See, e.g., Chemical Weapons Convention, supra note 17; Test-Ban Treaty, supra note 17 (establishing international organizations).

76 See generally Bauer, Beijer \& Bromley, supra note 39, at 174.

77 See U.N.G.A., supra note 6, at para. 27 (stating the response of Argentina, implying that the experience with other COPs inspired the proposal to create an ATT COP). 
from the express terms of the constitutive instrument 78 or by a decision of the CSP, 79 or even through a headquarters agreement. 80

Because the ATT treaty regime does have a Secretariat, it satisfies at least one of the two elements that the International Law Association considers are necessary for a treaty regime organization to be an international organization. ${ }^{81}$ Just as with the CSP, the ATT does not include any express terms on personality for the Secretariat, so the grant of personality will either need to be understood as implied in the ATT or the CSP will need to take some action granting or confirming that personality.

That being said, it is possible that the CSP's or Secretariat's nature might evolve over time. Treaty organs are still a relatively recent phenomenon in international law. They can be seen as part of a move away from more formal institutions towards informal mechanisms that are seen to be more effective. Consider, for example, the General Agreement on Tariffs and Trade ("GATT").82 When the GATT was first adopted in 1947, the vision was to also create an International Trade Organization. ${ }^{83}$ However, that effort was unsuccessful until the creation of the World Trade Organization in 1994. Thus, between 1947 and 1994 the GATT operated, certainly not by design, as an informal organization directed by regular meetings of the parties, a secretariat, and subsidiary bodies. ${ }^{84}$ It evolved informally to the point where the meetings of the parties continued the normative development of the GATT and the

78 See, e.g., UNOLA, Arrangements for Implementation 1993, supra note 55, at para. 4 ("[A]n international entity/organization with its own separate legal personality, statement of principles, organs and a supportive structure in the form of a Secretariat").

79 See FCCC Arrangements for Relocation 1996, supra note 57, at 7, 11(5) (granting secretariat an international personality by a decision of the CSP).

80 See FCCC, Administrative and Financial Matters Establishment of the Permanent Secretariat and Arrangements for its Functioning, U.N. Doc. FCCC/CP/ 1996/MISC.1, art. 4(1) (granting international personality through a headquarters agreement).

81 See Int'1 L. Assoc., Committee on Accountability of International Organizations, First report 5 (Feb. 1998) (listing elements that make a treaty regime an international organization).

82 General Agreement on Tariffs and Trade, Oct. 30, 1947, 55 U.N.T.S. 188 [hereinafter GATT].

83 See generally S.J. Rubin, The Judicial Review Problem in the International Trade Organization, 63 HARV. L. REV. 78 (1949).

84 See GATT, ANALYTICAL INDEX: GUIDE TO GATT LAW AND PRACTICE 1035 (6th ed. 1994) (describing organizational history of the GATT). 
subsidiary bodies monitored implementation and compliance. ${ }^{85}$ A similar evolution may take place for the ATT organs over the coming fifty years.

\section{CONVENING}

To begin operations, the CSP must first be convened. Under ATT article 17(1), CSP1 will be called by the Secretariat, having itself only been provisionally formed. ${ }^{86}$ Article 17(2) requires that this first meeting of the CSP be convened no later than one year following the entry into force of the ATT. ${ }^{87}$ The schedule for further meetings is at the discretion of the CSP. 88

At this point, CSP1 is planned to take place in August 2015. The precise date is planned to not conflict with other significant arms control meetings, such as the Non-Proliferation Treaty Review Conference scheduled for April and May 2015, and to allow sufficient time to prepare and permit additional states to adhere to the ATT.

Because of the needed urgency, the state parties decided to convene two preparatory conferences prior to CSP1. ${ }^{89}$ The first preparatory meeting for CSP1 was in Port-of-Spain on February 2324, 2015 and the second was in Geneva on 6-8 July 2015.90 All signatories to the ATT were invited to these meetings, as were select

85 See Decision of the Contracting Parties, Differential and More Favorable Treatment Reciprocity and Fuller Participation of Developing Countries (Nov. 28, 1979), B.I.S.D. (26th Supp.) 203 (1980) (describing normative evolution of GATT).

86 ATT, supra note 1 , at art. 17(1).

87 Id.

$88 \quad I d$.

89 See Virginia Gamba, Looking Ahead: Entry into Force and the First Conference of State Parties: Current State of Play and Preparations for the Conference of State Parties in Mexico at the British Group Inter-Parliamentary Union, U.N. Off. for Disarmament Aff'rs, London (Nov. 3-5, 2014), at 4, available at https://unodaweb.s3.amazonaws.com/wp-content/uploads/2014/10/ipu-revvg.pdf

[hereinafter UNODA Gamba, Looking Ahead] (noting that, at the time of writing, a meeting had already been held in Mexico, another would be held in Berlin, and that other governments had offered to host both "informal and formal" additional meetings "as needed during 2015.").

90 See UNODA, First Conference of States Parties to the Arms Trade Treaty available at http://www.un.org/disarmament/ATT/csp1/. Also id. (describing the informal consultations in Mexico City on September 8-9, 2014; Berlin on November 27-28, 2014; and Vienna on April 20-21, 2014). 
NGOs. ${ }^{91}$ Thus, the voice of states that have signaled intention to adhere to the ATT but have not yet done so will be considered in shaping the operations, and make for a more successful regime. Mexico has further offered to host CSP1,92 and will serve as chair of the preparatory meetings. ${ }^{93}$

Once convened, the CSP will direct the (then permanent) Secretariat to convene meetings periodically. ${ }^{94}$ This practice of periodic meetings is common to many CSPs, especially CSPs dealing with environmental law issues or functioning as an organ of a true international organization. ${ }^{95}$ This practice is historically uncommon among arms control treaties CSPs, which are usually convened only on an as-needed basis by the U.N. Secretariat or agency administering them, ${ }^{96}$ or by the CSP itself for special sessions. ${ }^{97}$ This is, of course, a generality only. Furthermore, a trend may be emerging for even arms control treaties to provide for periodic meetings. 98 The fact that the ATT must have periodic meetings is unusual in this regard and points to its special nature.

Article 17(1) further provides that the CSP shall meet at other times decided by the CSP. ${ }^{99}$ For example, article 17(5) explicitly permits the CSP to call special "[e]xtraordinary meetings."100 There are two possible triggers for an extraordinary meeting: either when the CSP determines that such a meeting is necessary, or when a state

91 Bauer, Beijer \& Bromley, supra note 39, at 3.

92 Mex. MFA, Mexico welcomes, supra note 63.

93 See Bauer, Beijer \& Bromley, supra note 39, at 3 (stating Mexico City will serve as chair).

94 ATT, supra note 1, at art. 17(1).

95 See Test-Ban Treaty, supra note 17, at art. II(B)(14) and (15) (noting that

"[t]he Conference shall meet in regular sessions, which shall be held annually, unless it decides otherwise" and providing for additional rules permitting special sessions of the Conference to be called).

96 See Cluster Munitions Convention, supra note 7, at art. 11(1) (setting out that "[t]he States Parties shall meet regularly in order to consider and, where necessary, take decisions in respect of any matter with regard to the application or implementation of this Convention").

97 See Chemical Weapons Convention, supra note 17, at art. VIII(B)(12) (noting that special sessions of the Conference to the Convention may be convened in various circumstances, including "[w]hen decided by the Conference").

98 See Inter-American Trafficking Convention, supra note 43, at art. XXI (noting, for example, that the "Consultative Committee" to the Convention "shall hold one regular meeting each year").

99 ATT, supra note 1 , at art. 17(1).

100 Id. at art. 17(5). 
party requests such a meeting in writing with the agreement of twothirds of the States Parties.101 The CSP will also have the power to create subsidiary organs. ${ }^{102}$ However, the ATT does not specify when any subsidiary organs would meet, whether future meetings would be periodic or on an as-needed basis, or whether those meetings would occur at the same time as meetings of the CSP. 103

The only decision the CSP must take at its first meeting is to decide on rules of procedure, which will be discussed in more detail below.104 However, the CSP would be wise to also address important logistic issues, such as the structure and financing of the Secretariat and future meetings, in order to not unnecessarily impede the operation of the ATT, and to make for a more effective Secretariat. In addition, the first CSP might also consider developing national reporting templates and a plan of work to ensure that the momentum of the ATT is not lost. By way of contrast, the practice of the CSP of the Convention on Cluster Munitions was to postpone important funding decisions for the implementation support unit, 105 and it appears that momentum to reach agreement may have been lost as a result.

$101 \quad I d$.

102 ATT, supra note 1, at art. 17(4)(f).

103 In addition, some CSPs have created subsidiary organs that might convene separately or contemporaneously with the principal organ. See UNFCCC Convention Bodies: Conference of the Parties, available at http://unfccc.int/ essential_background/convention/convention_bodies/items/2629.php ("The SBSTA [Subsidiary Body for Scientific and Technological Advice] and the SBI [Subsidiary Body for Implementation] have traditionally met in parallel, at least twice a year. When they are not meeting in conjunction with the COP, the subsidiary bodies usually convene at the seat of the secretariat."). But, there does not appear to be a requirement that this be the case here.

104 ATT, supra note 1, at art 17(2).

105 See, e.g., Cluster Munitions Convention CSP, Non-paper submitted by the coordinators on general status and operation of the Convention on the subject of resource mobilization for the financing of the future ISU (Jan. 2014) available at http:/ / www. clusterconvention.org/files/2014/01/Non-paper-financing-of-ISU-Coordinatorson-General-Status-and-Operation-of-the-Convention.pdf [hereinafter Cluster Munitions CSP, Non-paper] ("At the 4th MSP, States Parties agreed that the issue of the funding model for the Implementation Support Unit (ISU) be deferred to the 5MSP, but that consultations on the issue of the funding model will be ongoing."); Bauer, Beijer \& Bromley, supra note 39, at 3 ("The 2008 Convention on Cluster Munitions (CCM) entered into force in 2010, but states are still trying to agree a funding model for the treaty's implementation support unit (ISU)."). 
[Vol. 36:4

\subsection{Representatives}

The ATT does not provide any terms or provisions on the representatives to the CSP. This is unfortunate, since most other treaties creating CSPs do provide this direction. ${ }^{106}$ However, the practice of the ATT will most likely follow those other CSPs. CSPs and similar organs commonly permit one representative from each state. ${ }^{107}$ It is typical for each representative to be accompanied by advisors and experts. ${ }^{108}$

It is also not clear how the CSP will evaluate the credentials of representatives. It is the frequent practice of international organizations to form a sub-committee for this purpose or delegate this function to the Secretariat. ${ }^{109}$

\subsection{Observers}

Similarly, the ATT is silent in relation to observers to the CSP. Some CSPs permit observers, 110 with some going so far as to permit observer participation. ${ }^{111}$ For example, some environmental law

106 For examples of treaties with provisions, see Inter-American Trafficking Convention, supra note 43 , at art. XXI(1); Chemical Weapons Convention, supra note 17, at art. VIII(B)(9); Test-Ban Treaty, supra note 17, at art. II(B)(12); Ramsar Convention, supra note 9 , at art. 7(2).

107 See Inter-American Trafficking Convention, supra note 43, at art. XXI(1) ("The Consultative Committee shall consist of one representative of each State Party."); Chemical Weapons Convention, supra note 17, at art. VIII(B)(9) (noting that "[e]ach member shall have one representative in the Conference"); Test-Ban Treaty, supra note 17, at art. II(B)(12) (similarly providing that "[e]ach State Party shall have one representative in the Conference"); Ramsar Convention, supra note 9, at art. 7(2) (noting that "[e]ach of the Contracting Parties represented at a

Conference shall have one vote").

108 Chemical Weapons Convention, supra note 17, at art. VIII(B)(9).

109 See, e.g., CITES Sixty-fifth meeting of the Standing Committee, Geneva (Switzerland), 7-11 July 2014, SC summary record, at 11.2, available at http://www.cites.org/sites/default/files/eng/com/sc/65/E-SC65-SumRec-

DRAFT-08.04.15.pdf (providing "guidance" on evaluating submission of credentials). See generally 1971 U.N, Jurid. YB at 219.

110 See Anti-Personnel Mines Convention, supra note 7, at art. 11(4) (noting that various non-parties "may be invited to attend . . . meetings as observers"); Cluster Munitions Convention, supra note 7, at art. 11(3) (similarly permitting various nonparties to be invited to attend such meetings).

111 See generally Kyoto Protocol, supra note 11, at art. 13(2); CITES, supra note 10 , at art. XI(7). 
CSPs permit non-state actor observer participation. ${ }^{112}$ It is likely that the ATT CSP will adopt the normal practice of international institutions and provide itself the discretion to admit observers. Practice to date, in relation to the preparatory meetings for the CSP, supports this conclusion. ${ }^{113}$ Certainly, state and international organization actors, as well as International Committee of the Red Cross, could be observers, as could other reputable civil society organizations. The difficulty for the CSP will be determining which organizations should be invited and in particular, whether weapons manufacturers or other non-state actors should be included. The initial practice developing at the preparatory meetings has been to exclude arms manufacturers. ${ }^{114}$ However, this is likely due to the fact that the civil society participants were organized by an arms control organization rather than the arms industry, which may limit the precedent value of this approach to date.

Subsidiary body organs may have different rules on observers, sometimes accrediting them together with the CSP or, in other cases, accrediting them separately. Similarly, different rules may apply in

112 See, e.g., Kyoto Protocol, supra note 11, at arts. 13(2) and 13(8) (permitting "[p]arties to the Convention that are not Parties to this Protocol" to participate as observers in the proceedings of session of the Conference of the Parties serving as the meeting of the Parties to this Protocol."); UNFCCC, supra note 11, at art. 7(6) ("The United Nations, its specialized agencies and the International Atomic Energy Agency, as well as any State member thereof or observers thereto not Party to the Convention... Any body or agency, whether national or international, governmental or non-governmental, which is qualified in matters covered by the Convention, and which has informed the secretariat of its wish to be represented at a session of the Conference of the Parties as an observer ...."); CITES supra note 10, at art. XI(7) (permitting non-state parties, suitably qualified, to be admitted at meetings of the Conference unless at least one-third of Parties object). See also Arms Trade Treaty Legal Response Network, Survey of Rules of Procedure for Conferences of States Parties Governing International Treaties, available at http://controlarms.org/en/wp-content/uploads/sites/2/2014/09/Survey-ofParticipation-Rules-of-Procedure-for-CSP.pdf (discussing "participation in the Meetings or Conferences of States Parties as set forth in the CSP Rules of Procedure for each treaty.").

113 See Bauer, Beijer \& Bromley, supra note 39, at 2-3 ("Meeting invitations will be extended to those governments that have signed or ratified the ATT and NGOs that have played a role in promoting it.").

114 See Rachel Stohl, First Formal Arms Trade Treaty Preparatory Meeting Held in Port of Spain, Trinidad Stimson Center, (Mar. 2, 2015),

available at http://www.stimson.org/spotlight/first-formal-arms-trade-treatypreparatory-meeting-held-in-port-of-spain-trinidad/ ("Specifically, the United States wanted to allow industry and civil society organizations that did not support the object and purpose of the ATT to participate in the meetings, which - under the process established by Mexico - was not permitted."). 
relation to the participation of observers. In certain environmental law CSPs that are created by a separate protocol, the CSP of the initial treaty is only permitted to implement the protocol.115 This means that parties to the protocol who are not parties to the initial treaty may only participate as observers when the CSP of the initial treaty is not acting in its capacity as CSP of the protocol.116 Of course, these issues will only arise if the ATT CSP creates subsidiary bodies or the States Parties adopt protocols to the ATT.

\subsection{Staff}

It will be helpful at this point to comment on the staffing issue of the Secretariat. In contrast to the political organ of the CSP, the Secretariat is generally understood to be an independent organ staffed by international civil servants. ${ }^{117}$ The U.N. Secretariat remains the model secretariat for staffing practices; the general practice among other secretariats is to follow U.N. recruitment, staffing and human resources policies, 118 such as promotion and salary. ${ }^{119}$ Independence of staff does not mean that these employees will be unaccountable to the political organs; rather, their independence requires that they answer to all of the States Parties

115 See, e.g., Kyoto Protocol, supra note 11, at art. 13(1) ("The Conference of the Parties, the supreme body of the Convention, shall serve as the meeting of the Parties to this Protocol.").

116 See id. at art. 13(2) (noting that "[p]arties to the Convention that are not Parties to this Protocol may participate as observers" at conferences under the Protocol but decisions may only be taken by parties).

117 See, e.g., Chemical Weapons Convention, supra note 17, at art. VIII(D)(46), (47) ("Each State Party shall respect the exclusively international character of the responsibilities of the Director-General, the inspectors and the other members of the staff and not seek to influence them in the discharge of their responsibilities."); Test-Ban Treaty, supra note 17, at art. II(D) (52) (relevantly noting that "[i]n the performance of their duties, the Director-General, the inspectors, the inspection assistants and the members of the staff shall not seek or receive instructions from any Government or from any other source external to the Organization" and shall refrain from taking any actions "that might reflect adversely on their positions").

118 See T.G. Weiss, International Bureaucracy: The Myth and Reality of the International Civil Service, 58 INT'L AFF'RS 287-89, 293 (1982) (noting that one of the pressures faced by international officials is achieving geographical balance among the staff).

119 See U.N., International Civil Service Commission, Common System Members, available at http://icsc.un.org/about/members.asp (providing information on the U.N. Secratariat's structure). 
jointly ${ }^{120}$ and perhaps in an even more abstract way, the Secretariat is accountable to the treaty regime generally. ${ }^{121}$

The ATT states that the Secretariat will be "adequately staffed" and work within a "minimized structure" to fulfill its responsibilities. ${ }^{122}$ In addition, the employees must "have the necessary expertise to ensure that the Secretariat can effectively undertake [its] responsibilities." 123 These terms set up a need for a careful balance between having as small of a Secretariat as possible and empowering the Secretariat such that it is able to discharge its duties under the ATT, as well as potentially any other duties or tasks assigned to the Secretariat by the CSP. It is possible for a Secretariat to be quite small and function effectively, 124 though size has a clear link to the ability of the treaty organ to adopt a more or less proactive position.

As for leadership, most secretariats have an officer or council that heads the bureaucracy. ${ }^{125}$ The ATT does not specify how the leadership should be structured or even what the title of the officer should be. To date, two states have proposed candidates for "Head" of the Secretariat. ${ }^{126}$

120 See Weiss, supra note 120, at 288-89 ("Each international official is expected to approach decision-making objectively, taking into account the opinions of all nations and the impact of any decision upon the globe as a whole.").

121 See J. Depledge, The ORganization of Global Negotiations: CONSTRUCTING THE ClimATE CHANGE REgIME 65-6 (2005) (relevantly noting that the Secretariat must be impartial while "[f]undamentally" serving two masters, acting both "as the guardian of the climate change regime" while also being "subservient to, and dependent on, the will of the parties, having been established to serve them.").

122 ATT, supra note 1 , at art. 18(2-3).

123 Id. at art. 18(2).

124 After all, the Convention on Conventional Weapons has a staff of two. See Tim Caughley, Report to the Open-Ended Task Force on the Implementation Support Unit 60 (Sept. 1, 2010) available at http://www.apminebanconvention.org/ fileadmin/APMBC/ISU/ISU-Evaluation-Final-1Sept2010.pdf (discussing the effectiveness of the ISU of the Mine Ban Convention).

125 Typically, secretariats have either a Secretary-General or Director-General. At other times, there is an Executive Council. See, e.g., Chemical Weapons Convention, supra note 17, at art. VIII(C); Test-Ban Treaty, supra note 17, at art. II(C) (noting the creation of an Executive Council in the Test-Ban Treaty).

126 See Bauer, Beijer \& Bromley, supra note 30, at 5 (describing Finland and Sweden's "proposed candidates for Head of [the] Secretariat"). 


\subsection{Seat}

Perhaps significantly, the ATT CSP and Secretariat have no headquarters or permanent seat designated in the treaty.

This practice is not unusual for CSPs, 127 in keeping with their more "informal status." 128 True international organizations have a fixed headquarters. ${ }^{129}$ Even CSPs hosted by an existing international organization will necessarily have a permanent headquarters insofar as the secretariat serving the organ already has a permanent seat.130 Independent CSPs are not limited in this way. One advantage of this structure is that the CSP can rotate its meetings or convene at a location more relevant for the topics on the agenda.

However, it is left unclear whether the CSP or the Secretariat will determine the site of the next meeting. Some treaties expressly provide that the CSP may determine its places of meeting, 131 but the ATT is silent. It might be implied that the CSP determines its place of meeting by reading the provisions in ATT article 17 on the power to control the manner of meeting, specifically paragraphs 3 (budget decisions) and 5 (time of meetings). Also, it could be understood to reside in the power of the CSP by comparison to the normal practice of CSPs as the principal organ of the treaty regime. ${ }^{132}$ Regardless of which organ takes up this task, the selection of the meeting site might become a leverage point in securing the implementation of and compliance with the ATT; hosting the meeting can serve as a reward for compliance. Thus, in keeping with the specific tasks allocated to the organs, it might be better practice for this, seemingly mundane, item to be on the CSP agenda even though the ATT appears to contemplate that the permanent Secretariat will convene future meetings.

127 See generally Anti-Personnel Mines Convention, supra note 7, at art. 11; Convention on Cluster Munitions, supra note 7, at art. 11; CITES, supra note 10, at art. XII.

128 See International Legal Personality, supra note 50 (describing the informal structure of certain CSPs).

129 See, e.g., Preparatory Commission Resolution, supra note 33, at art. 3; Chemical Weapons Convention, supra note 17, at art. VIII(A)(3) (noting the location of the headquarters/seat of the organization).

130 See supra notes 24-25 and accompanying text.

131 See generally Inter-American Trafficking Convention, supra note 43, at art. XXI (3-5).

132 See, e.g., Test-Ban Treaty, supra note 17, at art. II(B)(24)(“The Conference shall be the principal organ of the Organization."). 
As of the time of this writing, the States Parties had not yet determined the seat of the Secretariat. While the CSP might not need a fixed seat, it is very impractical for the Secretariat not to have one. There are a wide variety of considerations for where to best locate it, ranging from a city with a large number of established international organizations and well-developed infrastructure to a location outside of the usual "UN city" network that might provide better geographic distribution and be closer to areas of concern. In the preparatory meetings leading up to CSP1, three states have submitted formal offers to host the Secretariat: Austria, Switzerland, and Trinidad and Tobago. ${ }^{133}$ Another option might be to have geographically distributed regional centers that could be closer to areas of concern, with the headquarters in a more familiar city. ${ }^{134}$

\section{RULES OF PROCEDURE}

One of the first tasks of the CSP upon being convened is to adopt its rules of procedure. Here again the ATT is not entirely clear about any specific rules of procedure, apparently leaving the issue to the CSP. ${ }^{135}$ However, permitting the CSP to decide on its own rules of procedure is a typical practice of treaty regimes. ${ }^{136}$

The ATT only specifies rules of procedure for adopting the rules of procedure. Article 17(2) provides that the rules of procedure shall be adopted by consensus. ${ }^{137}$ Other than this first act of adopting

133 Bauer, Beijer \& Bromley, supra note 39, at 5.

134 See Weiss, supra note 120, at 302 (discussing the potential benefits of decentralizing international institutions' operations). See id. ("Decentralisation could also counterbalance the increasing bureaucratic depersonalisation so characteristic of large societies and institutions. International secretariats could encourage grass-roots participation and initiate small-scale projects in many parts of the world, in which the final decision-making authority would be vested in global civil servants in the field and local communities rather than in staff at headquarters.").

135 ATT, supra note 1, at art. 17(2).

136 For examples of other treaty regimes where the CSP determines its own rules of procedure, see Inter-American Trafficking Convention, supra note 43, at art. XXI(7) ("The Consultative Committee shall prepare its own internal rules of procedure and shall adopt them by absolute majority"); Preparatory Commission Resolution, supra note 33, at art. 8 ("The Commission shall...adopt its rules of procedure..."); Chemical Weapons Convention, supra note 17, at art. VIII(B)(13).

137 ATT, supra note 1 , at art. 17(2). 
rules of procedure, however, the ATT provides no requirements for how decisions are to be taken in the future, so this first decision will be crucial for how the CSP effectively pursues its tasks.

There was not much feedback from states on their views on the eventual rules of procedure for the ATT CSP. The only formal suggestion submitted was the intervention of Mauritaniasubmitted on behalf of the League of Arab States - that suggested that decisions of the five-year review process, though not necessarily decisions by the CSP, must be based on consensus. ${ }^{138}$ The disadvantage of consensus, however, is that it is poorly defined in international institutional law and could be a means to prevent decision-making. 139

In terms of the probable rules of procedure, the ATT CSP is not likely to re-invent the wheel. The norm for environmental law CSPs is for all states to be represented, speak, and vote equally. ${ }^{140}$ Certain states have adopted a negative consensus method by which states are bound unless they opt out. ${ }^{141}$ Other CSPs, on the other hand, reach decisions primarily using consensus, ${ }^{142}$ though permitting voting should consensus not be possible. ${ }^{143}$

138 See U.N. Secretariat, Compilations of views, May 10, 2012, supra note 38, at para. 7 (stating the response of Mauritania on behalf of the League of Arab States).

139 See Report of the sixth meeting of the COP to the Convention on Biological Diversity, U.N. Doc. UNEP/CBD/COP/6/20, (May 27, 2002), paras. 294-324, ann. I (illustrating that not only can it be difficult to reach consensus, there can be varying understandings of what "consensus" means). See also Ray Acheson \& Beatrice Fihn, The Failure of Consensus, No. 6.10 ARMS TRADE TREATY MONITOR (Mar. 29, 2013), available at http://www.reachingcriticalwill.org/ images/documents/Disarmament-fora/att/monitor/ATTMonitor6.10.pdf, 1-2 (discussing the use of consensus to prevent decision-making at the Conference on Disarmament).

140 See, e.g., CITES, supra note 10, at art. XI(7) (outlining representation); Ramsar Convention, supra note 9, at art. 7(2) ("Each of the Contracting Parties represented at a Conference shall have one vote, recommendations being adopted by a simple majority of the votes cast, provided that not less than half the Contracting Parties cast votes.").

141 See generally Convention on Long-Range Transboundary Air Pollution, Nov. 13, 1979, 1302 UNTS 217 [hereinafter LRTAP Convention].

142 See Anti-Personnel Mines Convention, supra note 7, at art. 8(6) ("The Meeting of the States Parties or the Special Meeting of the States Parties shall make every effort to reach a decision by consensus. If despite all efforts to that end no agreement has been reached, it shall take this decision by a majority of States Parties present and voting.").

143 See, e.g., Test-Ban Treaty, supra note 17, at art. II(B)(22); Preparatory Commission Resolution, supra note 33, at art. 6; Chemical Weapons Convention, supra note 17, at art. VIII(B)(18), Anti-Personnel Mines Convention, supra note 7, at art. 8(6). 
Procedural issues, though, often do not require consensus, and can range from two-thirds to simple majority, perhaps with a weighing mechanism. ${ }^{144}$ The distinction between procedural and substantive issues then also needs to be specified, and significant issues such as the agenda, amendments to be tabled for consideration, establishing subsidiary organs and shifting from consensus building to voting on the merits can be considered procedural.

\section{FINANCING}

With rules of procedure in place, the CSP must adopt financial rules under article 17(3). These rules will cover the ATT CSP, 145 the Secretariat, ${ }^{146}$ and any subsidiary bodies created later. ${ }^{147}$ In addition to preparing the funding rules, the CSP will also establish the annual budget for itself ${ }^{148}$ and the Secretariat. ${ }^{149}$ The Secretariat does not have independent budget powers. ${ }^{150}$

One of the less noticed strengths of treaty bodies over true international organizations is their cost. It cannot be overlooked that international organizations generally require large headquarters and sometimes branch offices, large staff with international relocation, training and pension obligations, translation services,

144 See, e.g., Biodiversity Convention, Rule 40(1) of the Rules of Procedure, U.N. Doc. UNEP/CBD/COP/1/17, ann. III (Jan. 1995) (requiring that parties make every effort to ensure that decisions are unanimous or, if not unanimous consensus is not possible, that decisions are approved by a two-thirds majority); UNFCCC, Draft Rules, Rule 42, U.N. Doc. FCCC/CP/1996/2; (May 22, 1996) (providing that it is not necessary for the parties have unanimous support for convention actions); Report of the Conference of the Parties on Its Fifth Session, U.N. Doc. FCCC/CP/1999/6, I 14, available at http://unfccc.int/resource/docs/ cop5/06.htm (allowing procedural changes to be instated without consensus).

145 See ATT, supra note 1, at art. 17(3) ("The Conference of States Parties shall adopt financial rules for itself ...")

146 See id. ("[The CSP] shall adopt financial rules ... governing the functioning of the Secretariat...").

147 See id. ("[The CSP] shall adopt financial rules ... governing the funding of any subsidiary bodies it may establish ...").

148 See id. ("At each ordinary session, it shall adopt a budget for the financial period until the next ordinary session.").

149 See id. at art. 17(4)(e) ("[The CSP] shall consider and decide the tasks and budget of the Secretariat.").

150 Id. 
security, etc. 151 Of course, the reverse can be true for a moveable place of meeting, as the costs of transporting secretariat functions can be considerable, depending on the institution. ${ }^{152}$ The preference to avoid new expensive bureaucracies is part of the reason for the growth in treaty regimes, ${ }^{153}$ so it can be assumed that the ATT CSP will adopt financial rules that seek to minimize costs, and this interest might influence other choices such as the headquarters of the CSP and Secretariat.

Some treaties provide for a financing structure, ${ }^{154}$ but the ATT does not. This omission of financial rules in the ATT means that a great number of financing issues remain unresolved, including the costs of meetings and all of the activities of the CSP and other organs, and it means that the parties have no agreement on the method by which costs will be allocated. The options include voluntary contributions or mandatory assessments (fixed or varying, equal or proportional), or an approach combining the two (such as mandatory assessments for the Secretariat and voluntary contributions for various projects directed by the CSO, etc.). These issues are in turn linked to the structure of the organs themselves. For example, embedding the treaty organs into an existing organization could be significantly cheaper than a freestanding organ. ${ }^{155}$

As noted above, there is no provision on how this decision on financial rules shall be made. In addition, article 17(3) provides that the CSP shall have the authority to adopt the operating budget for the financial period until the next meeting of the CSP. 156 Since the

151 See SCHERMERS \& BLOKKER, supra note 19, at §§ 925-936 (describing the various needs of international organizations to function correctly).

152 See id. at $\S 487$ (discussing the strengths of having a mobile headquarters as opposed to one that is fixed).

153 See Andrew Hurrell \& Benedict Kingsbury, The International Politics of the Environment: An Introduction, in THE INTERNATIONAL POLITICS OF THE ENVIRONMENT 34-5 (1992) [hereinafter Hurrell \& Kingsbury] ("[T]he dominant view among states is that to meet new environmental needs over the next few years UNEP should be strengthened, and perhaps the balance of its activities adjusted more to Geneva and New York, rather than a new institution of general competence established.").

154 See, e.g., Preparatory Commission Resolution, supra note 33, at art. 11; Chemical Weapons Convention, supra note 17, at art. VIII(A)(7); UNFCCC, supra note 11, at art. 11 (outlining financial mechanisms).

155 See generally Cluster Munitions CSP, supra note 75 (describing a wide variety of funding structures).

156 See ATT, supra note 1, at art. 17(3). 
CSP will not be in session, this provision primarily governs the budget of the Secretariat and any subsidiary bodies.

\section{POWERS}

Once convened, the CSP will adopt rules of procedure and establish financing arrangements. After that, the CSP will then commence its substantive work.

Originally, CSPs were quite weak and very clearly advisory in nature. Parties to treaties creating international organizations generally tend to be relatively comfortable vesting such organizations with strong roles. ${ }^{157}$ In contrast, however, CSPs began with largely consultative roles. ${ }^{158}$ Later, these bodies were increasingly permitted to review the operation or implementation of the treaty under which they were authorized. ${ }^{159}$ Incrementally, CSPs have received greater and greater powers, including, for example, financial authority and the power to create subsidiary organs. ${ }^{160}$ Especially in the field of environmental law, treaty-based CSPs, such as the Antarctic Treaty Consultative Meeting or human rights treaty-based committees, such as the Human Rights Committee, have often been tasked with unusually broad powers to create new rules, amend treaties, and reach decisions on treaty compliance and enforcement. ${ }^{161}$ Law-making powers can vary from the more formalistic approach of adopting new treaty protocols by

157 See Churchill \& Ulfstein, supra note 54, at 628-634 (reviewing the types of responsibilities organizations to conventions perform).

$158 \quad I d$.

159 For example, the Cf. Ramsar Convention, supra note 9, at art. 6 was amended in 1987 to authorize periodic conferences to regulate the implementation of the treaty. See the same article following its amendment in 1987, Amendments to Articles 6 and 7 of the Convention on Wetlands of International Importance, Especially as Waterfowl Habitat, May 28, 1987, 1996 UKTS No. 13 (relevantly introducing regular conferences to discuss implementation, make recommendations, and ensure that these recommendations were taken into consideration).

160 Cf. Ramsar Convention, supra note 9, at art. 6(2); CITES, supra note 10, at art. XI(3) with ATT, supra note 1, at art. 17(4) (allowing the CSP to create groups to help it in accomplishing its tasks).

161 See Antarctic Treaty, arts. IX, XII, Dec. 1, 1959, 402 U.N.T.S. 71; International Covenant on Civil and Political Rights, arts. 28, 40-42, 999 U.N.T.S. 171; Optional Protocol to the International Covenant on Civil and Political Rights, art. I-XIV., Mar. 23, 1976, 999 U.N.T.S. 302 (detailing the means by which CSP can act in accomplishing the tasks given it). 
active consensus that provide for new or modified obligations, such as in the Kyoto Protocol, 162 to the more functional approach of adopting annexes attached to the underlying treaty 163 or recommendations for implementing the treaty, ${ }^{164}$ which bind the state parties unless they actively opt-out. 165

Some trends can be identified. Human rights CSPs tend to be able to consider amendments to a treaty that can only be adopted by a review conference. ${ }^{166}$ They also do not usually review parties' compliance with a treaty. Instead, they often delegate that function to an expert council or quasi-judicial body that cannot adopt binding orders. ${ }^{167}$ Environmental law CSPs, on the other hand, are usually able to aggressively review compliance and adopt amendments. ${ }^{168}$ Arms control treaties resemble human rights treaties more in this regard and usually do not empower the CSP alone to reach findings on treaty compliance and amend a treaty. ${ }^{169}$ Thus, the parties to the ATT may generally view the ATT CSP's powers as similarly narrow

162 Kyoto Protocol, supra note 11, at art. 20. See also Ramsar Convention, supra note 9, at art. 10 ("[T]his Convention shall enter into force for each Contracting party four months after the day

of its signature without reservation as to ratification, or its deposit of an instrume nt of ratification or accession.").

163 See, e.g., CITES, supra note 10 (listing, for example, endangered species in appendices and permitting parties to the CITES to propose amendments to these appendices).

164 See, e.g., Ramsar Convention, supra note 9, art. 6(2)(d) (permitting parties to, for example, make recommendations regarding aspects of wetland management covered by the Convention).

165 See Sebastian Oberthür, Montreal Protocol: 10 Years After, 27 ENVIRON. POL'Y \& L. 432, 433 (1997) (requiring states to opt-out of new amendments to the treaty if they do not want to be subject to such amendments).

166 See, e.g., Optional Protocol to the International Covenant on Civil and Political Rights, Mar. 23, 1976, 999 U.N.T.S. 302 (stating the requirement that amendments be reviewed before being implemented).

167 See, e.g., U.N., Human Rights Bodies, available at http:/ / www.ohchr.org/ EN/HRBodies/Pages/HumanRightsBodies.aspx (citing Human Rights Committee, Committee against Torture, Committee on the Rights of the Child as treaty-based bodies and putting forth the role and powers of these third party entities used to review amendments to the convention).

168 See, e.g., Ramsar Convention, supra note 9 (as amended in 1987) (broadly granting the CSP amendment powers); London Convention, supra note 15 (as amended in 1978) (allowing the CSP to make amendments so as to ensure the ends of the convention are met); CITES, supra note 10 (as amended in 1979); Basel Convention, supra note 11 (as amended in 1995) (allowing the CSP amendment power).

169 See, e.g., Test-Ban Treaty, supra note 17, at art. II(B)(16), (17) (permitting conferences to be convened as either "Amendment" or "Review" conferences). 
in this way. In this light, the United States' comments, that it did not intend to create a body that could enforce the treaty, are instructive. ${ }^{170}$

\subsection{Powers of the CSP}

The ATT CSP's powers are outlined below. Notably, the ATT states that the CSP "shall" undertake its tasks rather than "may" undertake them. ${ }^{171}$ However, there is no specific mechanism for review of the CSP's negligence to discharge its tasks. Further, whether the CSP should be considered an international institution with responsibility for violating international law in the discharge of its functions for this question is also unclear and is linked back to the question of its personality.

Specifically, the ATT authorizes the CSP to: (a) review the implementation of the treaty, including developments in the field of conventional arms; (b) consider and adopt recommendations regarding the implementation and operation of the treaty, in particular the promotion of its universality; (c) consider amendments to the treaty in accordance with article 20; (d) consider issues arising from the interpretation of the treaty; (e) consider and decide the tasks and budget of the Secretariat; (f) consider the establishment of any subsidiary bodies as may be necessary to improve the functioning of the treaty; and (g) perform any other function consistent with the treaty. ${ }^{172}$ This article will largely follow this structure when discussing the powers of the CSP below, with minor deviations where necessary.

\footnotetext{
170 See USDOS, US Signs ATT, supra note 47 ("There will be no mandate for an international body to enforce an ATT.").

171 ATT, supra note 1, at art. 17(4) (noting that the CSP "[shall]" carry out certain tasks).

$172 I d$. at art. 17.
} 
[Vol. 36:4

\subsubsection{Review implementation of the ATT}

First, the ATT CSP shall "[r]eview the implementation of this Treaty, including developments in the field of conventional arms". 173

Consulting on how to implement a treaty is a task given to CSPs under arms control treaties. ${ }^{174}$ At least for environmental law CSPs, most CSPs have some sort of a complementary monitoring or supervisory role in this regard.175 Usually, when undertaking review of treaty implementation, States Parties have an obligation to exchange information or report on implementation of the obligations. ${ }^{176}$

173 Id. at art. 17(4)(a) ("Review the implementation of this Treaty, including developments in the field of conventional arms.").

174 See Anti-Personnel Mines Convention, supra note 7, at art. 8(1) (relevantly recording the parties' agreement to consult regarding implementation of the Convention); Test-Ban Treaty, supra note 17, at art. II(A)(1)(establishing the Comprehensive Nuclear Test-Ban Organization to, in part, "ensure the implementation of [the Treaty's] provisions" and "provide a forum for consultation and cooperation among State Parties"); Chemical Weapons Convention, supra note 17, at art. VIII(B)(20) ("The Conference shall oversee the implementation of this Convention.").

175 See CITES, supra note 10, at art. XI(3) (noting that parties at the relevant CSP shall "review the implementation" of the Convention, including receiving and considering reports presented); Bonn Convention, supra note 11, at art. VII(5) (similarly requiring the CSP to "review the implementation of this Convention", and, as part of that, to "receive and consider any reports presented"); Basel Convention, supra note 11, at art. 15(5) ("[T]he Conference of the Parties shall keep under continuous review and evaluation the effective implementation of this Convention."); UNFCCC, supra note 11, at art. 7(2)(e-g) (noting that the relevant CSP "shall keep under regular review the implementation of the Convention" and make "the decisions necessary to promote the effective implementation of the Convention," including taking into account parties' implementation and regular reports on the Convention); Biodiversity Convention, supra note 11, at art. 23(4) (noting similarly that the relevant CSP shall keep implementation of the Convention under review, including by considering and adopting amendments).

176 See Anti-Personnel Mines Convention, supra note arts. 7, 8 (listing transparency measures requiring reporting by parties as well as consultation and cooperation regarding implementation and compliance); Inter-American Trafficking Convention, supra note 43, at art. XX(1)(a), (b) (establishing a Consultative Committee responsible for, amongst other things, promoting cooperation and exchange of information between parties); Cluster Munitions Convention, supra note 7, at art. 6 (listing obligations of cooperation and assistance, including "the right to participate in the fullest possible exchange of equipment and scientific and technological information concerning the implementation of the Convention."); Preparatory Commission Resolution, supra note 17, at art. 14, 18, and 19 (listing the Commission's responsibilities in ensuring the fulfillment of the requirements of the Treaty); UNFCCC, supra note 11, at arts. 11 and 12 (listing 
For the ATT, each state party has an obligation to report to the other States Parties via the Secretariat. ${ }^{177}$ However, the CSP is not expressly empowered to consider those reports under article 17. Nonetheless, it is safe to say that the CSP must have an implied power to consider such reports in order to discharge its general power to review implementation.

This does not mean, however, that the ATT CSP can necessarily review States Parties' measures for compliance with the treaty. One noticeable omission is that, unlike treaties giving such powers to environmental law CSPs, the ATT does not explicitly provide the CSP with authority to do this task. The CSP may only review implementation generally,178 without necessarily identifying violators. The question here is whether this power to review implementation generally, along with articles 17(4)(b) (adopting recommendations), $17(4)(\mathrm{d})$ (considering interpretation issues), 17(4)(e) (establishing tasks for the Secretariat), and 17(4)(g) (performing any other task), imply the authority for the CSP to review specific measures (or omissions) by member states for compliance with the ATT. ${ }^{179}$ Given the fact that other CSPs have carried out evaluations of compliance by member states, the ATT CSP could take this more aggressive approach. Certainly, one of the advantages of having an independent treaty body is the creation of a forum for assessing treaty compliance rather than having to depend on individual states invoking the treaty in their bilateral relations. Given the lack of strong enforcement mechanisms, a "name-and-shame" process would appear to be the most powerful tool for inducing compliance. That tool would be undercut if the CSP would not review measures taken by specific states. Although this more vigorous approach might make sense, the CSP must expressly decide to exercise this power, and provide related funding if necessary.

If indeed the CSP interprets its authority under article 17(4)(a) to provide for substantive evaluation of state compliance with the ATT

obligations to establish a mechanism to provide financial resources and to exchange information relevant to the Convention).

177 See ATT, supra note 1, at arts. 11(6), (13) (encouraging and requiring reporting by state parties to report on measures taken and details of relevant imports and exports).

178 See id. at art. 17(4)(a) ("The Conference of States Parties shall .. . [r]eview the implementation of this Treaty, including developments in the field of conventional arms.").

179 See generally ATT, supra note 1, art. 17(b), (d), (e), (g). 
then presumably it will do so by applying the normal interpretive technique of the law of treaties, along with the default rules on state responsibility. 180 Another question is whether the CSP would then take on a quasi-judicial character, and, in turn, whether it would receive, inter alia, state complaints, third party complaints, and amicus curiae submissions, and whether it would need to adopt rules of procedure that provide for fair hearing and rights of participation. Presumably, the CSP will not take on this character.

To get a better sense of the expected powers of the ATT, we can look at the views of the States Parties. During the negotiation of the ATT, several states submitted on the importance of review or follow up mechanisms in the treaty. ${ }^{181}$ Many agreed that there should be

180 See VCLT, supra note 61, at arts. 31-32 (establishing the rules to be used in interpretations); Int'l L. Comm'n, James Crawford, Spec. Rapp., Draft Articles on State Responsibility, U.N. GAOR, 56th Sess., Supp. No. 10, U.N. Doc. A/56/10, at I 76 (2001) (providing text on the responsibility of the states for international wrongful acts).

181 See, e.g., U.N. Secretariat, Compilation of views, May 10, 2012, supra note 29 (response of Algeria, paras. VI(6),5, Mar. 29, 2012) ("[R]egular review of the treaty would make it possible to evaluate its effectiveness and to modify it as needed."); id. (response of Bulgaria, para. VIII, Mar. 30, 2012) ("We consider appropriate the establishment of a review mechanism. Conferences to review the status, implementation and scope of the treaty should be conducted at mutually agreed interval."); id. (response of Costa Rica, para. VIII, Mar. 30, 2012) (supporting "the establishment of an assembly of States Parties and a five-yearly review conference."); id. (response of the former Yugoslav Republic of Macedonia, para. VII. 10 April 2012) (noting that it "supports the proposal on annual meetings of States Parties to promote dialogue and ensure smooth functioning of the treaty, as well as the holding of review conferences every five years following its entry into force"); id. (response of Kenya, para. VIII, Mar. 30, 2012) (supporting "the establishment of an assembly of States Parties and a review conference to be held every five years"); $i d$. (response of Mauritania (on behalf of the League of Arab States), para. 7, Mar. 30, 2012) (supporting a "consensus"-based five-year review process); id. (response of Poland, para. VII, Apr. 4, 2012) ("It is advisable that the treaty foresee a review mechanism such as review conferences every five years after entry into force to ensure appropriate implementation."); id. (response of Senegal, para. 15, Apr. 27, 2007) (supporting five-year review conferences); U.N. Secretariat, Compilations of views, May 10, 2012, supra note 38 (response of Switzerland, para. VIII, 3 April 2012) ("Switzerland supports the establishment of an assembly of States Parties and a quinannual review conference."); $i d$. (response of Trinidad and Tobago (on behalf of the Caribbean Community), Mar. 31, 2012) ("CARICOM supports the principles as set out in the Chair's non-paper, in particular the references to the Charter of the United Nations."); id. (response of the U.K., Mar. 30, 2012) ("The United Kingdom fully supports the preamble as set out in the Chair's non-paper and in particular its strong humanitarian focus."); id. (response of Zambia, Apr. 18, 2012) (supporting "the convening of a review conference every five years to provide an opportunity for States Parties to review the implementation of the treaty and consider proposed amendments to the instrument"); id. (response of the U.K., para. VIII, Mar. 30, 2012) (recording that the U.K. "fully supports . . . 
a meeting, at least once per five years, for substantive review of the treaty, potentially including discussion on amendment of the treaty text. 182 This review conference mechanism is quite the norm for arms control treaties. ${ }^{183}$

However, support for the creation of a meeting of the parties for review was often contrasted with support for an intercessional meeting, probably annually, that would specifically only have the power to review implementation of the treaty generally. ${ }^{184}$ For example, Bulgaria suggested that the intersessional meeting would merely "enhance implementation, promote the universality of the treaty and request or provide assistance." 185 The former Yugoslav Republic of Macedonia (FYROM) submitted that the meetings of the States Parties should be annual but that the role of these meetings should be to "promote dialogue and ensure smooth functioning of the treaty". ${ }^{186}$ Poland argued that the intersessional conference should serve as a "forum of consultations and preparatory work." 187 Switzerland viewed the review function as involving the review of the treaty instrument and acting as an "information broker", i.e. it

the establishment of an assembly of States Parties and a five-yearly review conference"); id. (response of Zambia, para. VIII, Apr. 18, 2012)("Zambia submits that the treaty should include the establishment of an assembly of States Parties and a five-yearly review conference."); UNGA, Towards an arms trade treaty, 2007, supra note 6, at pt. II (response of Argentina, para. 27, July 2, 2007) (supporting the possibility of "periodic review" to enable updates and adaptations to the instrument); id. (response of Bulgaria, June 1, 2011) ( supporting "launching a United Nations-based process aimed at achieving an agreed regulatory framework for arms transfers (an arms trade treaty)."); id. (response of Hungary, para. 23, May 8,2007 ) (proposing various options for regular review processes).

182 See supra note 181.

183 See, e.g., Anti-Personnel Mines Convention, supra note 7, at art. 12; (requiring review conferences every five years); Non-Proliferation Treaty, supra note 7, at art. VIII(3) (setting out requirements relating to review conferences); Final Declaration of the Third Review Conference of the Parties to the Convention on the Prohibition of the Development, Production and Stockpiling of Bacteriological (Biological) and Toxin Weapons and on their Destruction, Doc. BWC/CONF.III/23, part II. at arts. XI and XII. [hereinafter Biological Weapons Convention] (allowing parties to propose amendments and setting out a mechanism for regular review conferences).

184 See infra notes 127-31.

185 U.N. Secretariat, Compilation of views, May 10, 2012, supra note 29 (response of Bulgaria, para. VIII, Mar. 30, 2012) (suggesting during intersessional periods, "State parties meet annually or biannually to enhance implementation, promote the universality of the treaty and request or provide assistance.").

186 U.N. Secretariat, Compilation of views, May 10, 2012, supra note 29 (response of the former Yugoslav Republic of Macedonia, para. VII, Apr. 10, 2012).

187 Id. (response of Poland, Apr. 4, 2012). 
would "collate and analyze the information provided and, if needed, to bring the information into a comparable form." 188 Ukraine believed that the periodic conferences would "ensure, inter alia, the harmonious interpretation and implementation of the treaty." 189 In addition, Kenya submitted that the treaty needed a dispute settlement mechanism, but it did so only in reference to the obligation to resolve disputes peacefully under article 2(3) of the U.N. Charter. ${ }^{190}$

On the basis of the comments from states, the Chair produced a "non-paper" suggesting that there be an "Assembly of States Parties" (later "CSP") that met periodically and that this meeting would be distinct from the "Review Conference" at which amendments would be decided. ${ }^{191}$ Thus, the negotiating history suggests that a distinction should be made between the five-year meetings, which have significant powers of review and later evolved into the Review Conference, and the intercessional meeting that merely engaged in dialogue and prepared for the Review Conference, which evolved into the CSP.

Furthermore, many states that are issuing views on the ATT took the position that the CSP should be relatively weak in terms of its powers to review implementation. Cuba viewed the only necessary organ of this type as being an "implementation support unit" that would essentially perform only the roles of the Secretariat, and which "should not take on reporting, inspection, review, assessment or representative duties." 192 Some states suggested that the CSP

188 UNGA, Towards an arms trade treaty, supra note 50 (response of Switzerland) (suggesting "a minimal structure should be set up within the United Nations to collate and analyse [sic] the information provided and, if needed, to bring the information into a comparable form. This unit could also act as an "information broker" on request of Member States.").

189 U.N. Secretariat, Compilation of Views, May 10, 2012, supra note 29 (response of Ukraine, para. VI, Mar. 27, 2012).

190 Id. (response of Kenya, para. VIII, Mar. 30, 2012) (supporting the "provision that States Parties consult and cooperate with each other to settle any dispute that may arise with regard to the application or interpretation of the treaty" and suggesting "that parties shall settle any dispute between them concerning the interpretation or application of the treaty by peaceful means in accordance with . . . the Charter of the United Nations").

191 See Rep. of the Preparatory Comm. For the U.N. Conference on the Arms Trade Treaty, U.N. Doc. A/CONF.217/1 (Mar. 7, 2012), Ann. II, Chair's non-paper, para. VII, §§ F-H (July 14, 2011) (recommending powers of amendment, and to establish an assembly of state parties and review conferences).

192 U.N. Secretariat, Compilation of views, May 14, 2012, supra note 29 (response of Cuba, paras. VI and VIII, Mar. 30, 2012). 
should share best practices or be a forum for consultations and/or cooperation. 193 Japan, singularly, proposed that the CSP should only review the management and listing of weapons that were controlled. ${ }^{194}$

Other states envisioned a more rigorous peer-review system of treaty implementation. ${ }^{195}$ Ukraine offered the bold suggestion that parties should submit reports on treaty implementation to a regular assembly meeting that would ensure implementation and assist with "making necessary conclusions" regarding implementation. ${ }^{196}$ Algeria went so far as to propose a "supranational monitoring or verification body" and "the use of non-State sources of information as a basis for action against a State". ${ }^{197}$ These views on stronger enforcement mechanisms were clearly in the minority, although some states remained very vague in their proposals. ${ }^{198}$

The negotiating positions are certainly not definitive representations of the final operating powers of the CSP. In the final draft of the ATT, clearly it appears that the parties wanted to distinguish between "big picture" powers of treaty amendment and

193 See, e.g., U.N. Secretariat, Compilation of views, May 14, 2012, supra note 29 (response of New Zealand, para. VI, Mar. 30, 2012) (recommending that the annual meetings simply be a place to "to follow up on the information contained in reports on arms transfers and to engage on their experiences with treaty implementation" in a spirit of "peer engagement" to assist with capacity-building"); id. (response of Poland, para. VII, Apr. 4, 2012) (noting that implementation may be facilitated through "the exchange of best practices"); UNGA, Towards an arms trade treaty, 2007, supra note 6 (response of Hungary, para. 23, May 8, 2007) ("Another separate or parallel option might be to establish a separate organization entrusted with ensuring the implementation of relevant arms trade treaty provisions and providing furthermore a forum for consultations and cooperation among States Parties.").

194 See UNGA, Towards an arms trade treaty, 2007, supra note 6 (response of Japan, para. 8, Apr. 30, 2007) (stating that the convention believes that the treaty should include a complete system of control over the transfer of all conventional arms).

195 See, e.g., id. (response of France, para. 34 (a), Apr. 23, 2007) (noting, interestingly, that France suggested either "a guide of best practices or a peerreview on control mechanisms"); id. (response of Lithuania, para. 10, Apr. 24, 2007) (suggesting the treaty should aim at "[e]stablishing operative provisions to monitor enforcement of the future arms trade treaty and review procedures to strengthen the full implementation of its provisions").

196 U.N. Secretariat, Compilation of views, May 14, 2012, supra note 29 (response of Ukraine, para. VIII, Mar. 27, 2012).

197 Id. at response of Algeria, para. VI(5) (Mar. 29, 2012).

198 See, e.g., UNGA, Towards an Arms Trade Treaty, 2007, supra note 6 (response of Italy, para. 13, May 10, 2007) (stating that "a review mechanism should be envisaged"). 
consideration of the treaty as an effective instrument in international relations by the Review Conference, from the on-going assessment of implementation and cooperation issues by the CSP. Looking at the various legal bases justifying action, there does appear to be room for the CSP to review individual cases of compliance and consult on resolution, perhaps even reaching findings on noncompliance. This power, however, will be based on the power to review implementation taken with the other powers in the ATT. This topic will be addressed in the sections that follow.

\subsubsection{Consider recommendations}

Secondly, the ATT CSP shall "[c]onsider and adopt recommendations regarding the implementation and operation of this Treaty, in particular the promotion of its universality." 199

Some CSPs are authorized to require exchange of expertise and/or training and/or financing, ${ }^{200}$ or require assistance in arms reduction and/or destruction. ${ }^{201}$ Other treaties that contain CSPs require resort to normal dispute settlement mechanisms outside of the CSP in the case of state-to-state disputes. ${ }^{202}$

Other treaties permit the CSP to have its own independent role in reaching findings on non-compliance. ${ }^{203}$ In some treaties, parties

199 ATT, supra note 1, at art. 17(4)(b).

200 See Inter-American Trafficking Convention, supra note 43, at art. XX(1)(c), (d) (providing for States Parties to "establish a Consultative Committee responsible for c) encouraging cooperation between national liaison authorities to detect suspected illicit exports and imports of firearms, ammunition, explosives, and other related materials; d) promoting training and exchange of knowledge and experience among States Parties and technical assistance between States Parties and relevant international organizations, as well as academic studies;"); Cluster Munitions Convention, supra note 7, at art. 6 (outlining ways in which States Parties can provide assistance to each other).

201 See, e.g., Anti-Personnel Mines Convention, supra note 7, at art. 6(4-5) (outlining States Parities commitment to aiding other States Parties in the clearance and destruction of anti-personnel mines); Cluster Munitions Convention, supra note 7, at art. 6(4-5) (detailing the assistance States Parties can provide to one another in the reduction or destruction of arms).

202 See generally CITES, supra note 10, at art. XVIII(2); Bonn Convention, supra note 11, art. XIII; Basel Convention, supra note 11, art. 20; Vienna Ozone Convention, supra note 11, art. 11(3), (4); Biodiversity Convention, supra note 11, art. 27; UNFCCC, supra note 11, art. 14(1-2).

203 See Montreal Protocol, supra note 11, at art. 8 (finding that "The Parties... shall consider and approve procedures and institutional mechanisms for 
may even inquire into each other's compliance and even refer matters for investigation, 204 or decide on "measures" to take in response to non-compliance ${ }^{205}$ but this latter practice remains unusual. In at least in one case, an arms control treaty permits inquiry into non-party practices. ${ }^{206}$

If there is a finding of non-compliance, other treaties are more explicit than the ATT in providing a list of possible remedies, ${ }^{207}$ or permitting remedies but leaving the scope open. ${ }^{208}$

Building on the prior section on review, the power of the ATT to substantively review individual state's compliance was not clear; it is also unclear whether the ATT CSP can attempt to compel

determining non-compliance with the provisions of this Protocol and for treatment of Parties found to be in non-compliance."); UNFCCC, supra note 11, at art. 14(1) ("In the event of a dispute between any tow or more Parties concerning the interpretation or application of the Convention, the Parties concerned shall seek a settlement of the dispute through negotiation or any other peaceful means of their own choice."); Kyoto Protocol, supra note 11, at art. 18.; Desertification Convention, supra note 11, at art. 27 ("The Conference of the Parties shall consider and adopt procedures and institutional mechanisms for the resolution of questions that may arise with regard to the implementation of the Convention.").

204 See, e.g., Anti-Personnel Mines Convention, supra note 7, at arts. 8(2), 8(5), 10(1) (giving procedures for ensuring states compliance); Cluster Munitions Convention, supra note 7, at art. 8(3), (6) (permitting the parties to look into one another's compliance with the convention); Test-Ban Treaty, supra note 17, at arts. $\mathrm{II}(\mathrm{A})(1),(\mathrm{B})(24),(25),(26)(\mathrm{g})$ (empowering the conference to oversee compliance with the convention); Preparatory Commission Resolution, supra note 17, at arts. 13 (permitting the commission to make all preparations needed to guarantee the operationalization of the treaty's enforcement regime).

205 See, e.g., id., at art. 8(18), (19); Test-Ban Treaty, supra note 17, at art. II(B)(24), (25), (26)(g) (discussing the process for handling non-compliance of states).

206 See Inter-American Trafficking Convention, supra note 43, at art. XX(1)(e) ("In order to attain the objectives of this Convention, the States Parties shall establish a Consultative Committee responsible for . . requesting from nonparty states, when appropriate, information on the illicit manufacturing of and trafficking in firearms, ammunition, explosives, and other related materials ... ").

207 See, e.g., Climate Change Conference of the Parties Dec. 10/CP.4, ann., paras. 6, 12 (1998) (specifically, "clarifying and resolving questions; providing advice and recommendations on the procurement of technical and financial resources for the resolution of these difficulties; providing advice on the compilation and communication of information."); Montreal Protocol, Moving of the Parties Dec. IV/5 (referencing the "list of measures that might be taken in respect of non-compliance.").

208 See Long-range Transboundary Air Pollution Exec. Body Dec. 1997/2, ann., para. 11, Jan 7, 1998 (reporting on the fifteenth session of the Executive Body of LTRAP). 
compliance. ${ }^{209}$ The ATT does give one example of a recommendation that the CSP could consider, specifically, that the CSP can consider how to promote the universality of the treaty.210 Some authorities, such as the UNODA, have advocated for a strong universalization policy to promote the ATT as a normative treaty, 211 and this may come to be. However, it shows that the kind of recommendations that the States Parties envisioned were not along the lines of a vigorous non-compliance procedure, but rather a more mild promotional approach. The ATT CSP does not appear to enjoy the same degree of authority to adopt rules as CSPs under other conventions. ${ }^{212}$ Some authorities have suggested that the power to review reports and issue findings on compliance is inherent in the power to consider reports. ${ }^{213}$ One possibility is that the CSP might issue a "recommendation" that takes the form of a proposed amendment or protocol, which States Parties were then invited to ratify. 214

\subsubsection{Interpretation of the ATT}

Thirdly, the ATT CSP shall "[c]onsider issues arising from the interpretation of this Treaty." 215

209 See also ATT, supra note 1, at art. 14 (stating that, "[e]ach State Party shall take appropriate measures to enforce national laws and regulations that implement the provisions of this Treaty.").

210 See id. at art. 17(4) (b) (recommending the CSP to strategically push for international implementation of its treaty).

211 See UNODA, Kane, Presentation, supra note 64 (describing UNODA's stronger advocacy for universalization treatment of ATT).

212 See Basel Convention Conference of the Parties Dec. II/12 (1994), available at http://www.basel.int/Portals/4/Basel\%20Convention/docs/meetings/cop/ cop1-4/cop2dece.pdf; Montreal Protocol Moving of the Parties Dec. II/8, Doc. UNEP/OzL.Pro.2/3 (providing rule adopting authority).

213 See SCHERMERS \& BLOKKER, supra note 19, at §§ 446, 1402-5 (examining the source of authority to review reports and comment on compliance issues).

214 See, e.g., P.H. Sand, Lessons Learned in Global Environmental Governance, 18 B. C. ENVTL. AfF. L. Rev., 213-14, 18 (1991) (reviewing various recommendations that have been presented to become ratified and discussing the need for international ratification of recommendations).

215 ATT, supra note 1, at art. 17(4)(d). 
Other CSPs engage in interpretation, usually implicitly, 216 though sometimes explicitly.217 This power should be distinguished from the practice of adopting subsequent agreements as a method of codifying treaty interpretations. ${ }^{218}$

In the case of the ATT, the CSP may "consider issues arising from the interpretation," 219 but it is not clear whether the CSP may issue interpretations of the ATT or simply consult on the interpretation. That being said, it will probably need to interpret the ATT in the course of evaluating the implementation in connection with its other duties.

It might be helpful to also take note of ATT article 19(1) providing for peaceful settlement of disputes over the "interpretation" of the ATT, which could take place outside of the CSP. ${ }^{220}$ Since the ATT expressly permits disputes over interpretation to be settled through "negotiations, mediation, conciliation, judicial settlement, or other peaceful means," it is not clear what is the role and legal effect of the CSP's interpretations. ${ }^{221}$ Since the ATT states that the role of the CSP is to "consider issues arising from the interpretation of this Treaty," it does not appear to provide for definitive interpretation.

There does not appear to be any special procedure required for interpretations of the ATT, though the CSP might adopt special procedures in those cases.

216 See Convention on International Trade in Endangered Species of Wild Fauna and Flora, Conference of Parties to the Convention, Res. CITES.CONF.9.24 (Nov. 1994) (listing "criteria for amendment of Appendices I and II"); Convention on International Trade in Endangered Species of Wild Fauna and Flora, Conference of Parties to Convention, Res. CITES.CONF.4.27 (Apr. 1983) (providing an "interpretation of Article XVII, paragraph 3, of the Convention" as a demonstration of the implicit interpretation role).

217 See WTO Agreement, supra note 14, at art. IX:2 ("the Ministerial Conference and the General Council shall have the exclusive authority to adopt interpretations of this Agreement and of the Multilateral Trade Agreements.").

218 Having the power to adopt interpretations does not generally exclude recourse to subsequent agreement or practice as an interpretive technique. See EC Chicken Cuts, Appl. Body Rep., WTO Case Nos. WT/DS269/AB/R, WT/DS286/AB/R, para. 273 WTO Appl. Body (Sep. 12, 2005) (finding no lex specialis relationship between article IX:2 and VCLT art. 31(3)). For a more detailed discussion on the legal effects of acts of interpretation, specifically as "subsequent agreements" or "subsequent practice" under the VCLT, see notes 61-63 and accompanying text.

219 ATT, supra note 1, at art 19(1).

220 Id.

221 Id. 
[Vol. 36:4

\subsubsection{Consider amendments}

The ATT CSP shall "[c]onsider amendments to this Treaty in accordance with Article 20." 222

States have always had the power to propose amendments to treaties, even without a CSP structure, ${ }^{223}$ so the ability to consider amendments is not new, but vesting specific power in the CSP is part of the emerging international institutional practice regarding CSPs. Initially in drafting the ATT, the language "in accordance with [Article 20]" did not appear.224 This limitation was added later presumably to ensure that the CSP does not have independent authority to amend the ATT without the protections in Article 20. This addition, along with the power being described as merely to "consider" amendments, leads us to conclude that the CSP is essentially a forum for discussing the need for amendments. ${ }^{225}$ This conclusion accords with the interpretation applied in other CSPs. 226

For the ATT, the lack of power to amend distinguishes it from many of the environmental law treaties where the CSPs are often much more powerful.227 Some CSPs have the power, perhaps as an

$222 I d$. at art. 17(4)(c).

223 See, e.g., Convention on Certain Conventional Weapons, supra note 7, at art. 8(1) ("At any time after the entry into force of this Convention any High Contracting Pay propose amendments to this Convention or any annexed Protocol by which it is bound.").

224 U.N. Final Conference on the Arms Trade Treaty, President's Non-Paper, 20 March 2013, available at http://www.un.org/disarmament/ATT/docs/ Presidents_Non_Paper_of_20\%20March_2013_\%28ATT_Final_Conference\%29.pd f.

225 ATT, supra note 1, at art. 17(4)(c).

226 See, e.g., Cluster Munitions Convention, supra note 7, art. 11(1), 12 (discussing the power of the States Parties to meet, review, and make decisions about the "implementation of this Convention"); Chemical Weapons Convention, art. VIII(B)(12) (allowing for sessions to be called to review the implementation of the Convention). But see also, Weapons Convention, supra note 22, art. XII (granting the CSP the power to call for a Review Conference to consider amendments).

227 See, e.g., London Convention, supra note 15 (detailing the power of the Contracting Parties to make amendments to the convention with a two-third majority vote) (Protocol adopted in 1978); CITES, supra note 10, at art. XVII (Protocol adopted in 1979) (stating that one third of the Parties will be sufficient for a meeting to be called where amendments can be considered, with two-thirds being sufficient for the amendments to be adopted); Bonn Convention, supra note 11, at art. X (stating that the Convention can be amended at any given meeting subject to a few regulations); Vienna Ozone Convention, supra note 11, at art. 6(4) (allowing for new 
alternative to amendment, to adopt protocols to the treaty. ${ }^{228}$ For regional treaties, it is more common to provide for adoption of protocols through diplomatic conferences rather than through the CSP, which is understandable given the smaller number of parties. ${ }^{229}$ These are not true legislative powers and any amendment or protocol must be ratified by the various states. 230

Where some CSPs can adopt changes without the need for subsequent ratification is in annexes to treaties. Some treaties contain annexes that provide greater elaboration of the treaty's coverage, and in most cases, these annexes may be amended by the CSP without the need for state ratification. ${ }^{231}$ Usually, the changes in the annex are adopted by majority vote without the possibility for dissenting members to avoid the new obligation by objection. While often merely fine-tuning the list of particular objects coverage, the changes to annexes can be significant. ${ }^{232}$ Other arms control CSPs

protocols which would promote the purpose of the Convention to be adopted); Montreal Protocol, supra note 11, at art. 11(4)(h) (stating that at meetings thee Parties will "[c]onsider and adopt, as required, proposals for amendment of this Protocol or any annex and for any new annex"); Biodiversity Convention, supra note 11, at art. 23(4)(d) (stating that the Parties can review and amend the Convention); Desertification Convention, supra note 11, at art. 22(2)(f) (establishing that Parties can make amendments).

228 See, e.g., Vienna Ozone Convention, supra note 11, at art. 8. See also Montreal Protocol, supra note 11, adopted by the CSP allowing for the adoption of protocols)(allowing the adoption of protocols in accordance with Article 2); Basel Convention, supra note 11, at art. 15(5)(d) (stating that the Parties are able to adopt protocols); Protocol on Liability and Compensation adopted by the CSP); UNFCCC, supra note 11, at art. 17 (allowing for protocols to be adopted at any session; Kyoto Protocol, supra note 11, adopted by the CSP also allowing for the adoption of protocols); Biodiversity Convention, supra note 11, at art. 23(4)(c) (allowing for the adoption of protocols).

229 See, e.g., UNEP Regional Seas Strategic Conventions 2013-2016 (Sept 29, 2014); Protocol to the 1979 Convention on Long-Range Transboundary Air Pollution (illustrating the dominance of using protocols to adopt international treaties).

230 See Kyoto Protocol, supra note 11, at art. 13(2) (discussing the difficulties of legislating international bodies).

231 Montreal Protocol, supra note 11; Bonn Convention, supra note 11; Basel Convention, supra note 11; CITES, supra note 10; London Convention, supra note 15.

232 See, e.g., 1979 UKTS No. 71; Res. LDC.50(16) (1993), 1995 UKTS No. 90 (wherein the CSP amended its annex and provided for regulations on waste incineration at sea); London Consultative Meeting of the Parties Res. LDC.49(16), 51(16) (1993), 1995 UKTS Nos. 89, 91; Montreal Protocol MOP Dec. II/1, Doc UNEP/OzL.Pro2/3 (adjusting the production and consumption of the controlled substances listed in Annex A to the Protocol); Montreal Protocol MOP Decs. IV/2, IV/3, Doc. UNEP/OzL.Pro.4/15, p13 at Decisions IV/2 and IV/3 (1992), available 
can also have this power to update a list of scheduled items, ${ }^{233}$ though it is unusual.

That being said, we have already observed that the CSP has the authority to consider interpretation of the ATT234 and perform other tasks not inconsistent with the ATT. ${ }^{235}$ These provisions, along with the usual presumption of intra vires, mean that the CSP might be able to asset a stronger role in the amendment process than initially appreciated. Even if it cannot amend the ATT outside of article 20, it can interpret the meaning of the terms as they already exist in the treaty. It is a fine line, sometimes, between aggressive interpretation and full amendment. For example, the ATT does not contain an annex of monitored items like other treaties in this study. Instead, the covered weapons are included in the treaty text at article 2.236 Unless the CSP later adopts an annex system, changes to the covered weapons will require a treaty amendment. It is likely that adopting an annex system would require an amendment itself.

However, since the CSP reserves the right to consider interpretations of the treaty, it could interpret the definitions of listed weapons with reference to expert information as a de facto, albeit limited, modification process. For example, article 2(1)(a) of the ATT covers "battle tanks." In turn, the list of weapons covered under that heading resembles the list maintained by the U.N. Register of Conventional Arms ("UNROCA") 237 and thus suggests that "battle tanks" should be interpreted in align with the UNROCA understanding. Thus, the interpretation of the UNROCA (perhaps by the UNODA) might already modify the understanding of the items covered under article 2(1)(a). In the alternative, the CSP might consider an interpretation that looks to the recent technological developments in the field of battle tanks to modify its understanding of "battle tanks" and render a recommendation to

\footnotetext{
at http://ozone.unep.org/new_site/en/committee_documents.php?committee_ $\mathrm{id}=1$ (noting the entry into force of Annex D to the Protocol on May 27, 1992);

233 See Test-Ban Treaty, art. II(B)(24), (25), (26) (describing the powers and functions of the conference).

234 See ATT art. 17(4)(d) ("The Conference of States Parties shall [c]onsider issues arising from the interpretation of this Treaty.").

235 See id. at art. 17(4)(g) ("The Conference of States Parties shall [p]erform any other function consistent with this Treaty.").

236 Id. at art. 2.

237 UNGA, United Nations Register of Convention Arms, Report of the Secretary-General, Add., UN Doc. A/69/124/Add.1 (Sep. 9, 2014).
} 
that effect. This process would have an effect similar to changes in covered weapons in an annex.

\subsubsection{Manage the Secretariat}

The ATT CSP shall "[c]onsider and decide the tasks and budget of the Secretariat." 238

Control over the Secretariat by the CSP is common in other CSPs. 239 In other CSPs, the organ may have a more detailed oversight of the extensive work of the Secretariat.240 However, for the ATT, not only can the CSP determine the finances of the organ, but also require the Secretariat to undertake certain tasks. It is not entirely clear how far this control goes. It could be that the CSP grants general authority to the Secretariat for operations or provides a specific listing of tasks and authorized expenditure. If the CSP adopts the normal practice of international organizations, it will reserve considerable discretion to the Secretariat to determine specific expenditure. Thus, the CSP does not have any explicit authority, other than financial authority, over the personnel policies of the Secretariat, though the CSP might attempt to assert control either through conditioning certain budget items or claiming implied general control over the operations of the Secretariat under articles 17(4)(a) (reviewing the implementation of the treaty to the degree that the Secretariat implements the treaty), 17(4)(d) (considering interpretation of the treaty to the degree that the CSP can interpret its own powers) or $17(4)(\mathrm{g})$ (performing any other function consistent with the treaty to the degree that the treaty does not forbid such oversight).

238 See ATT, art. 17(4)(e) (The Conference of the States Parties shall [c]onsider and decide tasks and budget of the Secretariat.").

239 See Preparatory Commission Resolution, art. 10 (listing the tasks "concerning the organization and work of the Technical Secretariat and requiring immediate attention" after the treaty enters into force); Test-Ban Treaty, art. II(B)(24), (25), (26) (describing the powers and functions of the Conference); Chemical Weapons Convention, art. VIII(B)(20) (describing the powers and functions of the Conference, including overseeing the activities of the Executive Council and reviewing compliance, among others).

240 See e.g., Preparatory Commission Resolution, art. 12 (listing the draft arrangements, arrangements and guidelines the Commission will develop). 


\subsubsection{Subsidiary Bodies}

When performing its tasks, the CSP may ask for assistance not only from the Secretariat. It can also establish subsidiary bodies. ${ }^{241}$

For other CSPs, the power to create subsidiary bodies is often implied, ${ }^{242}$ but for the ATT CSP, it is express. ${ }^{243}$ This decision to include express terms on point suggests two possible considerations: either the parties to the ATT understood international institutional law to apply and, thus, the CSP would naturally have the power to establish subsidiary bodies, or the parties to the ATT understood that the CSP would not be governed by international institutional law, thus, needing the express authority to create subsidiary bodies.

The CSP has the power to establish subsidiary bodies as may be necessary to improve the functioning of the ATT. ${ }^{244}$ Contrasted with the Secretariat, which is an organ created by the treaty itself, subsidiary bodies can be organs operating at the pleasure of the CSP. 245 While the CSP may only create subsidiary bodies where "necessary to improve the functioning of" the ATT, the CSP most likely enjoys a presumption that its interpretation of the best functioning of the ATT is correct, especially given its interpretative authority in article $17(4)(\mathrm{d})$. Thus, if the CSP determines that the creation of a subsidiary body is necessary, this interpretation will likely control. In addition, the use of the term "necessary" suggests the doctrine of "functional necessity" in international institutional law might be applicable. 246

Under general principles of international institutional law, a subsidiary body can only exercise those powers enjoyed by the parent organ and delegated to the subsidiary, but that does not

241 See ATT, art. 17(4)(f) (“The Conference of the States Parties shall [c]onsider the establishment of any subsidiary bodies as may be necessary to improve the functioning of this Treaty.").

242 For a description of the powers and functions of the conferences, see TestBan Treaty, art. II(B)(24), (25), (26); CITES, supra note 10, at art. XI(3)(e)

243 Id.

244 See supra note 177.

245 See supra note 177.

246 JAN KLABBERS, AN INTRODUCTION TO INTERNATIONAL INSTITUTIONAL LAW 32 35 (2d ed. 2009). 
mean that the subsidiary will not receive significant powers. ${ }^{247}$ For example, subsidiary bodies can receive a delegation of power to review non-compliance activities in accordance with the treaty.248 Types of subsidiary organs generally can be divided into several functional categories: (1) expert advice; ${ }^{249}$ (2) financial and assistance arrangements, ${ }^{250}$ and (3) implementation and/or compliance. ${ }^{251}$ For the ATT, possible subsidiary committees could be a monitoring committee or a sanctions recommendation committee, separating these contentious political issues from the state representatives.

Membership on these committees can be the same as the States Parties or can be independent experts. ${ }^{252}$

\subsubsection{Any Other Function}

Lastly, the ATT CSP may "[p]erform any other function consistent with this Treaty." 253 This provision functions as an openended catchall authorization, intend to ensure the effective operation of the CSP within the bounds of the ATT.

247 See e.g., 9/56 Meroni v High Authority [1957-8] ECR 133 (addressing the delegation of powers by the High Authority of the European Coal and Steel Community).

248 Montreal Protocol MOP Dec. II/5, Montreal Protocol MOP Dec. IV/5, Doc. UNEP/OzL.Pro4/15.

249 See, e.g., Subsidiary Body for Scientific and Technological Advice of the UNFCCC; Scientific Council of the Bonn Convention, available at https://www.wmo.int/pages/themes/climate/international_unfccc.php\#c_.

250 See, e.g., Montreal Protocol Multilateral Fund, available at http://www. unmfs.org/POLICYdoc/Policy60.pdf; UNFCCC, art. 1.1 (noting that the purpose of the agreement is to provide financial assistance); Global Environment Facility available at http://www.thegef.org/gef/whatisgef.

251 See, e.g., Montreal Protocol, supra note 11, at art. 8 (discussing the creation and institutionalization of mechanisms for determining non-compliance); Implementation Committee; LRTAP Convention, art. 7, 1994 Sulphur Protocol, Implementation Committee; UNFCCC, art. 10 (establishing a subsidiary body for implementation).

252 See, e.g., Montreal Protocol MOP Dec. II/5, Doc. UNEP/OzL.Pro.2/3 (1990) as amended by Dec. III/20, Doc. UNEP/OzL.Pro.3/11 (1991) (requiring that the Implementation Committee include ten members elected by the CSP, following "equitable geographical distribution"); Bonn Convention, supra note 11, art. VIII(2), Scientific Council (shall include "qualified experts").

253 See ATT art. 17(4)(g) ("The Conference of States Parties shall [p]erform any other function consistent with this Treaty."). 
Here, as well, this kind of provision is common for other CSPs, which permit them to consider other matters falling within the treaty. 254

Notwithstanding this catchall, it can safely be understood that the CSP cannot set aside such core provisions with regard to the terms of its own creation or limitations on its competence. 255

\subsubsection{Entering into international agreements}

One thing that is not included in the ATT is the CSP's ability to enter into international agreements with other international legal persons. While the question remains open whether the CSP is an international organization, one issue is the ability of the treaty bodies to enter into agreements. This concern will become more pressing if the CSP, and even more importantly, the Secretariat, create a permanent headquarters in a host state. The issues of privileges and immunities will be addressed separately below.

The first question is whether the CSP would have such authority. Certainly, those CSPs that are part of a true international

254 See, e.g., Anti-Personnel Mines Convention, supra note 7, art. 11 (describing the meetings of the states' parties); Inter-American Trafficking Convention, art. $\mathrm{XX}(1)(\mathrm{f})$ (noting the establishment of a Consultation Committee to "promoting measures to facilitate the application of this Convention"); Test-Ban Treaty, art. II(B)(24), (25), (26) (describing the powers and functions of the conference); Chemical Weapons Convention, art. VIII(B)(19) (describing the powers and functions of the conference); London Convention, supra note 15, at art. XIV(4)(f) ("Consultative or special meetings of the Contracting Parties shall keep under continuing review the implementation of this Convention and may, inter alia: consider any additional action that may be required."); LRTAP Convention, art. 10(2)(c); UNFCCC, art. 7(2)(m) ("The Conference of the Parties ... shall ... [e]xercise such other functions as are required for the achievement of the objective of the Convention as well as all other functions assigned to it under the Convention."); CITES, supra note 10, art. XI(3) (noting the power of the parties to review the implementation of the convention); Kyoto Protocol, art. 13; (discussing the rules of procedure and implementation for the Conference of the Parties); Ramsar Convention, supra note 9, art. 6 (approving Strategic Framework and guidelines).

255 See SCHERMERS \& BLOKKER, supra note 19, at § 915 (discussing the relationships between the U.N. and the member states); 15 U.N. JURID. YB 200-01 (1976) (noting cooperation between the United Nations and the Organization of African Unity); id. at 164-65 (1981) (discussing action of the General Assembly on the Namibia question). 
organization can enter into treaties via their host organizations. ${ }^{256}$ Most CSPs have not entered into binding international agreements, 257 but instead relied on parallel decisions by the CSP and the other party providing for certain rights and obligations. ${ }^{258}$ Even though agreements have not been widespread, MOUs between CSPs and other international persons can be an alternative. ${ }^{259}$

While admittedly it has not entered into force, the Vienna Convention on the Law of Treaties Between States and International Organizations or Between International Organizations states that the capacity of an international organization to conclude agreements is governed by the "rules of the organization." 260 The ATT contains no provision permitting the CSP to enter into international agreements, though the implied powers doctrine ${ }^{261}$ might permit it where it is necessary for the functions of the ATT. Some international organizations were not expressly granted authority to enter into international agreements, yet they have been using the

256 See generally Vienna Convention on the Law of Treaties between States and International Organizations or between International Organizations, Mar. 21, 1986, 25 ILM 543 (1986) [hereinafter VCLTIO].

257 But see Agreement between the Government of Canada and the Multilateral Fund for the Implementation of the 1987 Montreal Protocol regulating matters resulting from the establishment in Canada of the Multilateral Fund and its Organs, Nov. 23, 1998, UNEP/OzL.Pro/ExCom/25/68, Decision 25/75, para. 107 (concluding an agreement regulating matters resulting from the establishment in Canada of the Multilateral Fund for the Implementation of the 1987 Montreal Protocol and its organs); Agreement Concerning the Headquarters of the Convention Secretariat, U.N. - FRG-Secretariat of U.N. Framework Convention on Climate Change, June 20, 1996, FCCC/CP/1996/MISC.1 (documenting an agreement among the United Nations, the Government of the Federal Republic of Germany, and the Secretariat of the United Nations Framework Convention on Climate Change).

258 See, e.g., Climate Change COP Dec. 14/CP.1, art. 2, Jun. 6, 1995 (deciding that "the Convention secretariat shall be institutionally linked to the United Nations"); UNGA Res. 50/115,U.N. GAOR, 50th Sess., Supp. No. 49, Vol. 1, p. 174,U.N. Doc. A/50/49 (1995), available at <http://www.un.org/documents/ $\mathrm{ga} / \mathrm{res} / 50 /$ ares50-115.htm ("[e]ndorse[d] the institutional linkage between the Convention secretariat and the United Nations, as advised by the Secretary-General and adopted by the Conference of the Parties.")

259 See, e.g., Memorandum of Understanding Between the Conference of the Parties to the United Nations Framework Convention on Climate Change and the Council of the Global Environment Facility, Dec. 12/CP.2, annex, U.N. Doc. FCCC/ $\mathrm{CP} / 1996 / 15 /$ Add.1 (Oct. 26, 1996) (documenting the memorandum of understanding).

260 See generally VCLTIO, supra note 257, at art. 6.

261 See supra note 44, 192-94. 
implied powers doctrine. ${ }^{262}$ This approach has been supported by the UNOLA. ${ }^{263}$ In particular, the UNOLA regards the catchall provision of the UNFCCC as the basis for permitting either for the interpretation of treaty-making competence specifically or implied powers doctrine generally. ${ }^{264}$

If we agree that the CSP has the capacity to enter into agreements, the second question is whether this capacity is objective or subjective, such as whether the CSP can only enter into agreements with the States Parties to the treaty. In Reparations, the ICJ also held that the personality enjoyed by the U.N. was objective, as in it was opposable to any other international legal person, even that states that are not parties to the U.N. Charter. ${ }^{265}$ Formally, this holding appears to be limited to the U.N., although in practice it is applied beyond the U.N. and many organizations are treated as international legal persons by states not party to the constitutive treaty.

\subsection{Powers of the Secretariat}

Distinct from the CSP, the Secretariat of the treaty regime is not meant to be political and is usually viewed as merely an organ providing bureaucratic support to the regime. ${ }^{266}$

The U.N. Secretariat is the typical model267 and secretariats of true international organizations do not differ significantly from secretariats of treaty regimes. ${ }^{268}$

The precise duties assigned to a secretariat vary depending on the regime, but they usually include human resource management,

262 See AMERASINGHE, supra note 52, at 85; (discussing the debate surrounding the national and international legal personality of international tribunals).

263 See generally UNOLA Arrangements for implementation 1993, supra note 55, para 6.

264 Id. at para. 6 (citing UNFCCC, art. 7(2)).

265 Reparation for Injuries Suffered in the Service of the United Nations: Adv. Op., of April 11th, 1949, 1949 I.C.J. Reps. 174, 185-87.

266 See Weiss, supra note 120 at 289 (describing developments in international administration).

267 See U.N. Charter, art. 97 (detailing the structure of the U.N. Secretariat and the appointment of the U.N. Secretary General).

268 See generally P. SANDS \& P. KLEIN, BOWETT'S LAW OF INTERNATIONAL INSTITUTIONS 297-98 (5th ed. 2001); Churchill \& Ulfstein, supra note 54, at 647. 
procurement, and information management. ${ }^{269}$ In addition, a secretariat can represent the treaty regime in international relations. 270 Beyond those tasks, secretariats may also have unique duties linked to the objectives of the constitutive instrument. ${ }^{271}$ Treaties containing reporting obligations focus on receiving and distributing those reports. ${ }^{272}$ Although a secretariat's duties can include analysis and commentary on the contents of the reports. ${ }^{273}$

In discharging these duties, a secretariat will not be micromanaged by the CSP, and the precise degree of CSP control over a secretariat will vary from regime to regime. ${ }^{274}$ As a result, some secretariats have a wide degree of independence and can act very aggressively in pursuit of the treaty regime, while others are more dependent and passive. ${ }^{275}$ Two examples of secretariats that are widely considered very independent and active are those of the Biodiversity Convention and Desertification Convention. ${ }^{276}$ A more passive secretariat would be the UNFCCC Secretariat. 277

As for the ATT Secretariat, it is still too early to tell which approach it will take. In an unusual move, States Parties to the ATT negotiated specific provisions on the Secretariat's powers and role - perhaps implying a view that the organ's powers should be

269 SCHERMERS \& BLOKKER, supra note 19, at §442-68.

270 Id. at $\S 450$.

271 Id. at $\S 439$.

272 See Anti-Personnel Mine Ban Convention, supra note 7, at art. 8 (providing procedure for the reports to be distributed to the member states); Cluster Munitions Convention, supra note 7, at art. 6(3) (providing methods for distributing the given reports).

273 Kyoto Protocol, supra note 11, art. 8(3); Montreal Protocol, Report of the Fourth Meeting of the Parties to the Montreal Protocol on Substances that Deplete the Ozone Layer, 25 November 1992, U.N. Doc. UNEP/OzL.Pro.4/15, Annex IV. P 3; CBD, The CBD Secretariat, Role, http:// www.cbd.int/secretariat/role.shtml.

274 See generally F. Bierman \& B. SiebenHÜNER, EDS., MANAGERS OF GLOBAL CHANGE: THE INFLUENCE OF INTERNATIONAL ENVIRONMENTAL BUREAUCRACIES 225318 (2009), available at http:/ / www.academia.edu/2032349/Managers_of_Global_ Change_The_Influence_of_International_Environmental_Bureaucracies; Joanna Depledge, A Special Relationship: Chairpersons and the Secretariat in the Climate Change Negotiations, 7 GLOBAL ENVIRON. POL'y 45, 54 (2007).

275 See generally R. Sandford, Secretariats and International Environmental Negotiations: Two New Models, in INTERNATIONAL ENVIRONMENTAL TrEATY MAKING 27 (1992); S. Bauer, P-O Busch \& B. Siebenhüner, Treaty Secretariats in Global Environmental Governance, in F. BIERMAN, B. SIEBENHÜNER \& A. SCHREYÖGG, INTERNATIONAL ORGANIZATIONS IN GLOBAL ENVIRONMENTAL GOVERNANCE 174 (2009).

276 B. Siebenhüner, supra note 68, at 284; S. Bauer, supra note 68, at 300.

277 See generally P-O Busch, supra note 68, at 261. 
carefully circumscribed.278 However, while the initial negotiations contemplated an "Implementation Support Unit" ("ISU"), the final draft changed the title of the organ to "Secretariat," 279 perhaps suggesting a more vigorous organ. Much will depend on the decisions of the CSP (for example, those regarding funding of a secretariat, hiring its head, interpreting the ATT, etc.), or perhaps lack of decisions, and the unfolding relationship between two organs. Because it will be the only organ of the regime that will continue to act in between sessions of the CSP, the ATT Secretariat's complex duties might entail a wide degree of discretion (e.g. coordinating reports on highly technical weapons, and matching offers and requests for assistance). For example, the organ may need to take a very active role out of necessity. In fact, as the Secretariat develops expertise on these matters, the CSP might even consult with the secretariat for guidance and leadership in the future.

The specific tasks assigned to a secretariat include (a) receiving and distributing reports as mandated by this treaty; (b) maintaining and make available to States Parties the list of national points of contact; (c) facilitating the matching of offers and requests for assistance for treaty implementation, as well as promoting international cooperation as requested; (d) facilitating the work of the Conference of States Parties, which included making arrangements and providing the necessary services for meetings under this treaty; and (e) performing other duties as decided by the Conferences of States Parties. 280

The ATT demands that the Secretariat "shall" undertake all of these duties. ${ }^{281}$ This means that the organ has no discretion to refuse any of them. However, there may be some discretion to prioritize depending on its budget and financing structure. Furthermore, the Secretariat is accountable to the CSP. Although the ATT uses an

278 Compare ATT, supra note 1, at art. 18 with Convention on Certain Conventional Weapons, supra note 7 (absence of terms); Cluster Munitions Convention, supra note 7 (transparency obligations only).

279 Compare Chairman's Draft Paper (July 14, 2011), available at http://reachingcriticalwill.org/images/documents/Disarmament-fora/att/ prepcom3/docs/ChairPaper-14July2011.pdf (referring to the ISU); UNGA, The arms trade treaty, Report of the Secretary-General, UN Doc. A/66/166 (July 20, 2011) (same) with ATT, supra note 1, at art. 18 (mentioning the Secretariat).

280 ATT, supra note 1 , at art. 18.

281 See id., supra note 7, art. 18(3) (describing that the Secretariat has the responsibilities of receiving, making available and distributing reports as mandated by the ATT). 
unfortunately vague expression, "responsible to the CSP," to describe their relationship. ${ }^{282}$

Initially, in the ATT's negotiations, it was proposed that the Secretariat would have two additional tasks, (1) "[e]nsur[ing] the necessary coordination with the secretariats of relevant international and regional organizations and represent[ing] the Implementation Support Unit in meetings and activities of such organizations, as applicable;" and (2) "[c]onduct[ing] outreach to increase awareness of the Treaty regime and to promote the universality of the Treaty." 283 Although the objective of universalization was retained and vested in the CSP, both of these duties were dropped from the final draft. ${ }^{284}$ This history does not mean the Secretariat is unable undertake these tasks. The Secretariat could be assigned such duties by the CSP under article 18(3)(e) ("other duties").285 However, the treaty does not mandate the Secretariat to do them, and the CSP has the authority to retain more control over them if they are assigned.

\subsubsection{Distributing documentation}

The Secretariat will receive required reports from the member states and distribute them among the membership.286 Having reporting obligations is typical of other similar conventions, although some delegate the administration to a body outside the treaty regime, such as the U.N. Secretary-General. ${ }^{287}$ The ATT

282 Id.

283 Chairman's Draft Paper (July 14, 2011), available at

http:/ / reachingcriticalwill.org/images/documents/Disarmament-fora/att/ prepcom3/docs/ChairPaper-14July2011.pdf.

284 See id. at 17(4)(b) (stating that the conference of States Parties have the responsibility of considering and adopting recommendations regarding the implementation of the treaty).

285 ATT, supra note 1, at art. 18(3)(e)

286 See id., at 18(3)(a) (describing that the Secretariat has the responsibilities of receiving, making available, and distributing reports as mandated by the ATT).

287 See, e.g., Anti-Personnel Mines Convention, supra note 7, art. 8 (relating to the role of the U.N. Secretary-General); Cluster Munitions Convention, supra note 7, art. 6(3) (addressing the role of the Secretary-General). 
mandates a variety of reporting obligations, ${ }^{288}$ and in all cases the Secretariat is the point of contact for reporting. ${ }^{289}$ The Secretariat also serves the same function for the optional reporting mechanisms. ${ }^{290}$

One issue that remains unclear in the ATT is whether the Secretariat can have any substantive role or take initiative in the reporting obligation. Other treaty regimes provide that a secretariat may request information, respond to inquiries for information (for example, on other states' compliance), digest and summarize the contents of reports, and identify or comment on notable aspects of the reports-especially noncompliance. ${ }^{291}$ One reasonable step would be to make reports publicly available. ${ }^{292}$

Many secretariats take the approach of promulgating reporting or compliance guidelines. 293 State parties might take a variety of approaches to structuring their reports. This makes comparative compliance assessment difficult and potentially necessitates a standardized format. The Secretariat should be mindful of the preference of the States Parties to avoid duplicating work already undertaken by other treaty organs and organizations when discharging this task. ${ }^{294}$ By doing so, the Secretariat could promulgate reporting guidelines that are harmonized with (or integrated into) the many arms control agreements already in force

288 See, e.g., supra note 200, at 5(4), 13(1), 13(3). See also ATT, supra note 1, at art. 13(1) (discussing national measures), 13(2) (concerning measures addressing diversion).

289 ATT, supra note 1 , at art. 13(1)

290 See supra note 200, at 11(6), 13(2) (encouraging reporting of transferred conversion arms to other states party to the convention).

291 See, e.g., Test-Ban Treaty, art. 2(D)(43) (relating to the role of the secretariat in the treaty regime); Fourth Meeting of the Parties to the Montreal Protocol on Substances that Deplete the Ozone Layer, Copenhagen, Den., Nov. 23-25, 1992, Report of the Fourth Meeting of the Parties to the Montreal Protocol on Substances that Deplete the Ozone Layer, Annex V, U.N. Doc. UNEP/OzL.Pro.4/15 (Nov. 25, 1992) (discussing the role of the secretariat in the treaty regime).

292 See, e.g., CITES, supra note 10 at art. XII(2)(f) (finding that the Secretariat will have the function to publish and distribute editions of appendices and any information to help identification of species in those appendices within the treaty regime).

293 See, e.g., Ramsar Convention Secretariat 2007, Ramsar Handbooks for the Wise Use of Wetlands, available at http:/ / www.ramsar.org (providing guidelines).

294 See, e.g., supra note 50 (addressing the response of Bosnia and Herzegovina); $i d$. (discussing the response of Costa Rica); id. (discussing the U.K.'s response to work duplication of other treaty organs). 
that also require reporting. ${ }^{295}$ It was already mentioned above that the ATT reporting requirements are structured similarly to the UNROCA lists and the obligation under ATT article 5(3) to use the weapon descriptions used in the UNROCA classification system. ${ }^{296}$ For this reason, it is likely that the CSP could require reports to be structured similarly, if not harmonized and combined outright. Several States Parties have asked the UNODA how to combine their reporting obligations under the UNROCA and ATT, and the UNODA is currently studying the issue. ${ }^{297}$ The task of creating harmonized reporting templates could very well be assigned to the Secretariat, as will be discussed in more detail below.

295 See, e.g., G.A. Res. 46/36L, U.N. Doc. A/RES/46/36L (Dec. 6, 1991), available at http://www.un.org/Depts/ddar/Register/4636.html (creating UNROCA and requesting all U.N. member states to provide information on their imports and exports of weapons). Other arms control reporting regimes include: Wassenaar Arrangement on Export Controls for Conventional Arms and Dual-Use Goods and Technologies, Munitions List Categories ML1 \& ML2 (July 2014), available at http://www.wassenaar.org/guidelines/docs/5\%20-\%20Initial\% 20Elements.pdf; European Union annual report on arms exports, L335 OJ EU 99103 (Dec. 13, 2008); OAS Treaty No. A-64; ECOWAS Convention on Small Arms and Light Weapons, their Ammunition and Other Related Materials (June 14, 2006), available at http://www.ecosap.ecowas.int/en/ecosap/strategic_docs/ convention/convention_small_arms.pdf; Council Common Position 2008/944/CFSP (Dec. 8, 2008); G.A. Res. 62/26 (Dec. 5, 2007) (establishing the U.N Exchange of National Legislation on Transfer of Arms, Military Equipment and Dual-use Goods and Technology); G.A. Res. 60/69 (Dec. 8, 2005); G.A. Res. 59/66, U.N. Doc. A/RES/59/66 (Dec. 3, 2004), available at http://www.worldlii.org/int/ other/UNGARsn/2003/95.pdf; S.C. Res. 1540, U.N. Doc. S/RES/1540 (Apr. 28, 2004), available at http://www.treasury.gov/resource-center/sanctions/ Documents/1540.pdf (obliging states to adopt measures to prohibit certain nonstate actors from acquiring nuclear, chemical or biological weapons, and report on measures to the "1540 Committee," which is a subsidiary body of the U.N. Security Council); S.C. Res. 1518,, U.N. Doc. S/RES/1518 (2003), available at http:/ /www. customs.gov.sg/NR/rdonlyres/876D72D9-7B10-4881-9189-CC5E76B07CAC/ 21885/UNSCResolution15182003.pdf; G.A. Res. 58/42 (Dec. 8, 2003; G.A.Res. 57/66, I U.N. Doc. A/RES/57/66 (Nov. 22, 2002), available at http://www.worldlii.org/int/other/UNGARsn/2002/144.pdf (establishing the U.N. Exchange of National Legislation on Transfer of Arms, Military Equipment and Dual-use Goods and Technology); U.N. Programme of Action to Prevent, Combat and Eradicate the Illicit Trade in Small Arms and Light Weapons in All Its Aspects, U.N. Doc. A/CONF. 192/15 (July 20, 2001; OSCE, Document on Small Arms and Light Weapons, para. 1, § I (Nov. 24, 2000) Inter-American Convention on Transparency in Conventional Weapons Acquisitions (June 7, 1999).

296 However, it is important to observe that the reporting obligations under the ATT and U.N. ROCA are not identical. For example, reporting on small arms is required under the ATT but is only "voluntary" under the U. N. ROCA.

297 See supra note 64 (concerning the reporting obligations of states). 
In some treaty regimes, States Parties have even requested the assistance of the treaty regime secretariat when drafting their report, going so far as to delegate the entire preparation of the report. ${ }^{298}$ Some secretariats go beyond reporting guidelines and produce advice on correct implementation of the treaty. For example, some produce compliance handbooks ${ }^{299}$ or operational manuals. ${ }^{300}$ One issue that remains unclear in these cases is whether the treaty organ would bear some measure of shared responsibility if the reporting obligation did not comply with the ATT. The ATT merely says that the "Secretariat shall be responsible to States Parties," and from the context implies that the responsibility must be used in the sense of accountability. ${ }^{301}$

\subsubsection{Coordinating cooperation}

The Secretariat plays an important role in matching offers and requests from states for assistance in implementing the ATT. The Secretariat, for example, will develop lists of designated national points of contact for exchange of information, 302 and will, most likely use those lists to find implementation partners. ${ }^{303}$ A few questions arise in this context-namely whether the Secretariat must discharge this duty in confidence (especially vis-à-vis nonparty

298 See, e.g., United Nations, Convention to Combat the Desertification in Those Countries Experiencing Serious Drought And/Or Desertification, Particularly in Africa, Intergovernmental Negotiation Committee, declaration of June 17, 1994, A/ AC. 241/15/Rev.7, 33 I.L.M. 1328 (1994) (addressing issues for developing states); CITES, supra note 10, art. XII (2)(d), (g) (permitting the secretariat to ask for further information and report to the CSP if there is failure to comply with a request).

299 See, e.g., Ramsar Convention Secretariat 2007, RAMSAR HANDBOOKS FOR THE WISE USE OF WETLANDS (4th ed. 2010), available at http://www.ramsar.org (handbook).

300 See Test-Ban Treaty, art. 2(D) (44) (detailing development of an operation manual to guide the operation of the verification regime), available at http://www.ctbto.org/fileadmin/content/treaty/treaty_text.pdf.

301 See supra note 200, at 18(3) (listing the general responsibilities of the secretariat).

302 See supra note 200, at 5(6), 18(3)(b) (empowering the creation of national points of contact to exchange information).

303 See supra note 200, at 18(3)(c) (stating that the Secretariat should match offers of assistance with requests for assistance, and promote international cooperation as needed). 
observers) ${ }^{304}$ and the degree to which the Secretariat can take an active role in promoting assistance and cooperation. The ATT only provides that the Secretariat must "facilitate" assistance in implementation and cooperation. ${ }^{305}$

To compare, other secretariats have developed extensive capacity by building projects to promote implementation, even where this task is not in its constitutive instrument. 306 Activities could include engaging in direct advice to States Parties, developing training programs or consultation processes. ${ }^{307}$ But, as with many of the other considerations in the section, financing for these activities will be crucial to their operation. ${ }^{308}$

One alternative to active implementation assistance from a Secretariat would be for states to look to other actors for assistance in ATT implementation. For example, the UNODA is already providing assistance, on request, to states for implementation. ${ }^{309}$ In addition to developing programs for raising awareness and developing implementation legislation, UNODA has developed an "ATT Implementation Toolkit" to provide guidance on treaty implementation. ${ }^{310}$ This toolkit was introduced at the Berlin preparatory consultation for CSP1; similar programs are already underway at the UNODA centers in Lima, Lomé, and Kathmandu. ${ }^{311}$ With donor funding, the UNODA has also developed the U.N. Trust Facility Supporting Conventional Arms Regulation ("UNSCAR") for awarding funding on a competitive basis to ATT implementation projects by a variety of civil society

304 See, e.g., Montreal Protocol, art. 12(d)(f) (specifying the role of notifying non-party observers).

305 See supra note 200, at 18(3)(c).

306 See generally B. Siebenhüner, Administrator of Global Biodiversity: The Secretariat of the Convention on Biological Diversity, 7 BIODIV. \& CONSERV. 259, 266 (2007).

307 Id. at 269. See also Desertification Convention, supra note 11, Annex I, art. 18(4), Annex II, art. 8(3) and Annex III, art. 7(2) (describing the Secretariat's abilities to engage various consultative processes); Chemical Weapons Convention, supra note 17, art. VIII(D)(37), (38), (39), (42), (45) (describing the mechanisms by which the Secretariat can assist in accomplishing group tasks).

308 See generally Siebenhüner, supra note 223 at 265-6.

309 UNODA, Gamba, Looking ahead, supra note 62 at 5.

310 See generally UNODA, Gamba, Looking ahead, supra note 62 at 5; UNODA, Kane, Presentation, supra note 64 at 4.

311 UNODA, Gamba, Looking ahead, supra note 62 at 5. 
organizations. ${ }^{312}$ The European Union, in partnership with the UNODA, has created an EU ATT assistance package. ${ }^{313}$ The UNODA office in Lima has already developed an ATT implementation-training manual and has completed its first training session for experts and officials in the region. ${ }^{314}$

\subsubsection{Supporting the CSP}

As stated by the ATT, the final task of the Secretariat is to support the CSP. Among other duties, the Secretariat should specifically "(d) [f]acilitate the work of the Conference of States Parties, including making arrangements and providing the necessary services for meetings under this Treaty"; and "(e) [p]erform other duties as decided by the Conferences of States Parties." 315

Some duties in this category such as administrative, secretarial, and logistical services are very typical of a secretariat. ${ }^{316}$ Other duties such as circulating amendment proposals and convening future meetings of the CSP can be inferred. While neither of these duties is explicit in the ATT, both can be safely understood as assigned to the Secretariat. One source of amendment proposals are States Parties. ${ }^{317}$ Amendment proposals made by States Parties must be communicated to the Secretariat and, in turn, the Secretariat is charged with circulating other communications. ${ }^{318}$ While other treaties have made this task explicit, the ATT may implicitly make the Secretariat the conduit for all communication related to treaty

312 See id. (UNSCAR also provides funding for POA implementation projects, as well as projects addressing the interaction of the ATT and POA).

313 See generally UNODA, Gamba, Looking ahead, supra note 62 at 5; UNODA, Kane, Presentation, supra note 64 at 4 .

314 See generally id.; UNODA, Kane, Presentation, supra note 64 at 4 . .

315 ATT, supra note 1, at art. 18(3)(d).

316 See, e.g., Chemical Weapons Convention, supra note 17, art. VIII(D)(37), (38), (39), (42), (45) (stating the various responsibilities of the Secretariat); Test-Ban Treaty, supra note 17, art. II(D)(45) (describing the responsibilities of the Secretariat); Anti-Personnel Mines Convention, supra note 7, art. 8 (stating the responsibilities that the Secretariat has under the convention).

317 ATT, supra note 1, at art. 20(1).

318 See id. at art. 20(2) (stating the Secretariat's duty to circulate amendments and proposals that he or she receives). 
matters. ${ }^{319}$ In addition, while the first meeting of the CSP must be convened by the provisional Secretariat, 320 the permanent Secretariat will convene future meetings of the CSP, as directed, by the CSP although the power to do so is not specifically granted to the Secretariat. Furthermore, some tasks such as accounting could also be understood as implied, even though other treaty regimes make those tasks explicit. ${ }^{321}$ It will then be interesting to determine how much discretion the Secretariat has, for example, in inviting observers or members of civil society to future meetings of the CSP when the Secretariat's exercise's the power to convene meetings falls under the direction of the CSP itself. 322

Presumably, the Secretariat will have some role in providing similar support if the CSP creates any subsidiary organs, but there is no reason to think that the specific tasks need to be identical to those rendered to the CSP. For example, some secretariats have a special role in dealing with the reports of subsidiary organs composed of experts. ${ }^{323}$ For subsidiary organs drawing on a separate budget, a related concern would be the secretariats costs for those particular tasks. ${ }^{324}$

Looking at the catchall provision of (e), we can wonder what unwritten tasks the CSP might assign. Catchall provisions of this nature are quite common in other treaties that establish secretariats. ${ }^{325}$ Some tasks that may be relevant in the context of the ATT include administering lists of experts on substantive matters

319 See Test-Ban Treaty, supra note 17, art. II(D)(43) (stating that the Secretariat is directly responsible for conveying proposals that she receives).

320 See ATT, supra note 1, art. 17(1) (establishing the Secretariat's ability to convene meetings).

321 See, e.g., Test-Ban Treaty, supra note 17, art. II(D)(47) (establishing that the Secretariat is directly responsible for accounting requirements).

322 See Montreal Protocol, supra note 11, art. 12(e)-(f) (discussing the extent of the Secretariat's responsibilities regarding future meetings).

323 See, e.g., Kyoto Protocol, supra note 11, art. 8(3) (tasking the Secretariat with the responsibility of circulating reports from expert review teams); Chemical Weapons Convention, supra note 17, art. VIII(D)(37), (38), (39), (42), (45) (requiring the Secretariat to assist the various councils in performing the tasks assigned to them).

324 See, e.g., Cartagena Protocol on Biosafety to the Convention on Biological Diversity, Jan. 29, 2000, 2226 UNTS 257, art. 31(3) (declaring that costs incurred by the Secretariat shall be covered in a manner that is determined by the parties at the first meeting).

325 See, e.g. Chemical Weapons Convention, supra note 17 art. VIII(D)(37) (broadly stating that the Secretariat is responsible for all tasks assigned to it by the convention). 
such as weaponry technology and on procedural matters such as weapons inspection, ${ }^{326}$ or maintaining weaponry databases. 327

There are a number of tasks that could arguably fall under (d) or (e). Among others, they include conducting research on topical issues (e.g. emerging technologies), 328 preparing the agenda or executive summaries of documents, ${ }^{329}$ preparing of the draft budget, ${ }^{330}$ advising on procedural matters, ${ }^{331}$ drafting an annual report on operation of the treaty, 332 or even advising on compliance issues in reports. ${ }^{333}$ Although it is unusual, some secretariats have even been requested to conduct studies and advise the CSP on substantive matters ${ }^{334}$ or even draft proposals for adoption. ${ }^{335}$. Even

326 See Anti-Personnel Mines Convention, supra note 7, art. 8(9) (requiring the Secretariat to compile and distribute a list of qualified experts).

327 See Test-Ban Treaty, supra note 17, art. II(D) (42) (tasking the Secretariat with the responsibility to assist the States Parties in fulfilling their responsibilities).

328 See, e.g., UNFCCC, supra note 17, art. 8(2)(b) (requiring the secretariat to compile and transmit reports); Desertification Convention, supra note 11, art. 23(2)(c) (requiring the secretariat to specifically help affected developing country parties in compiling and communicating information required under the convention).

329 See, e.g., Chemical Weapons Convention, supra note 17, art. VIII(D)(37), (38), (39), (42), (45) (making the Director-General responsible for the organization and functioning of the advisory board); Test-Ban Treaty, supra note 17, art. II(D) (45)(detailing the Secretariat's duties regarding verification of compliance).

330 See Chemical Weapons Convention, supra note 17, art. VIII(D)(37), (38), (39), (42), (45) (requiring the Secretariat to prepare and submit a draft of the budget); Test-Ban Treaty, supra note 17, art. II(D) (45) (requiring the Secretariat to prepare and submit a draft budget).

331 See, e.g., Chemical Weapons Convention, supra note 17, art. VIII(D)(37), (38), (39), (42), (45) (requiring the Secretariat is responsible for assisting the conference and the Executive Council); Test-Ban Treaty, supra note 17, art. II(D) (45)(requiring the Secretariat to provide administrative and technical support to the conference and its organs).

332 See Test-Ban Treaty, supra note 17, art. II(D) (45) (requiring the Secretariat to prepare and submit to the Executive Council the draft report of the organization as well as any other reports required by the Treaty).

333 See, e.g., Kyoto Protocol, supra note 11, art. 8(3) (requiring that the Secretariat assist in meeting the requirements of the reports set forth by the Treaty); Montreal Protocol, Report of the Fourth Meeting of the Parties to the Montreal Protocol on Substances that Deplete the Ozone Layer (Nov. 25, 1992), U.N. Doc. UNEP/OzL.Pro.4/15, ann. IV. at 3 (stating the compliance requirements that the Secretariat is to provide assistance to the parties required to adhere).

334 See CITES, supra note 10, art. VIII(4)(b), (c) (advising on the action to be taken when a live controlled species is discovered) and art. $\mathrm{XII}(2)(\mathrm{c})$, (h) (undertaking technical studies and advising on decisions).

335 See Volker Röben, Institutional Developments under Modern International Environmental Agreements, 4 MAx PLANCK YB U.N. LAW 363, 423-24 (2000) (arguing 
procedural tasks such as drafting agendas may have effects on the substantive work of the CSP. ${ }^{336}$ Thus, they turn on the larger question of how active the Secretariat will be. In this comparative study, the secretariats of proper international organizations tended to take a more active role than those of treaty regimes. 337

Unlike the CSP, the Secretariat does not have the explicit task of interpreting the ATT; however, depending on the nature of the tasks assigned to it and the degree of discretion awarded, the Secretariat may need to interpret the treaty itself. It could be that the Secretariat (presumably its legal counsel) is asked to render legal advice on the application of the treaty to the CSP, 338 but the active interpretation could be inherent in many of the Secretariat's tasks. ${ }^{339}$ This inherent interpretation is the norm for other secretariats of the treaty regimes. 340

Lastly, unlike the CSP, the Secretariat has not been expressly granted the authority to create subsidiary bodies. It is certainly possible for a secretariat to have this power granted by the constitutive instrument, though that is more common for secretariats of true international organizations, 341 organs that under general principles of international institutional law are usually

that the Secretariat will be able to pre-structure the issues that are addressed at the meetings).

336 Id. at 424 (describing the influence that the Secretariat has due to its responsibility in setting the agenda and organizing the meetings).

337 See Test-Ban Treaty, art. II(D) (45) (describing the Secretariats role in the meetings); Chemical Weapons Convention, art. VIII(D)(37), (38), (39), (42), (45) (describing the Secretariats role and responsibilities)

338 See Röben, supra note 336 at 431, n. 212 (noting that the CITES secretariat once rendered an opinion that a CSP decision was incompatible with the treaty).

339 See, e.g., ATT, art. 18(3)(c) ("[f]acilitate the matching of offers of and requests for assistance for Treaty implementation ...").

340 For example, the Biodiversity Convention Secretariat has supported the implementation of the convention by compiling and synthesizing national reports, see CBD Secretariat, Role, http://www.cbd.int/secretariat/role.shtml, which is a more-involved process than the less-filtered process forwarding of reports to the Expert Review Teams conducted by the Kyoto Protocol, see art. 8(3) (discussing the review process, stating the Secretariat's responsibilities of circulation, and listing questions of implementation), and Desertification Convention, see art. 26(6) (laying out the Secretariat's role in communicating information to the Conference of the Parties and any subsidiary bodies).

341 See, e.g., Test-Ban Treaty, art. II(D)(45) (listing the functions of the Secretariat with respect to administrative matters); id. at art . II(D)(51) (noting the power of the Director-General as head of the secretariat to establish "temporary working groups of scientific experts to provide recommendations on specific issues"). 
regarded to have the inherent power to create subsidiaries. This power might be granted to it by the CSP or the CSP might exercise the power on behalf of the Secretariat.

\subsubsection{Compliance monitoring}

Moving beyond the powers that are express (or implied by express terms) in the ATT, the Secretariat has not been given the power to initiate an investigation of the compliance issue of the States Parties independently. That does not mean that such a power is impossible to grant to the ATT Secretariat, since other secretariats do enjoy it. ${ }^{342}$ In fact, Bosnia and Herzegovina did suggest in negotiations that the Secretariat should have a compliance monitoring function. ${ }^{343}$ In the final draft that power was not granted, and it seems difficult to identify whether it has been implied, although we may be able to understand that the Secretariat has the much more mild indirect monitoring function involved in receiving reports, as discussed above.

\subsubsection{Entering into international agreements}

Some secretariats of treaty regimes are able to engage in negotiations, communications, and corporations among different international parties to a degree. This engagement can be mere diplomatic coordination among regimes or even negotiating binding agreements. Quite a few regimes authorize the Secretariat to take its own initiative to coordinate with other regimes, ${ }^{344}$

342 See Test-Ban Treaty art. II(D)(42), (43) (vesting the Technical Secretariat's responsibilities of verification of compliance with the Secretariat); Chemical Weapons Convention, art. VIII(D)(37), (38), (39), (42),(45) (establishing that the Technical Secretariat shall carry out the verification measures provided for in this Convention).

343 See UNGA, Towards an arms trade treaty, supra note 6 (response of Bosnia and Herzegovina, para. 24) (arguing that the secretariat should be confined to "serve as a point of contact for national reports and information sharing, capacitybuilding assistance and as a basis for any fact-finding mechanism").

344 See generally UNEP World Conservation Monitoring Centre, Synergies and Cooperation: A Status Report on Activities Promoting Synergies and Cooperation between Multilateral Environmental Agreements, in Particular Biodiversity-Related Conventions and Related Mechanisms, Status Report (May 2004), available at http:/ /www.unepwcmc.org/system/dataset_file_fields/files/000/000/048/original/Synergies 
although the usual practice is for the CSP to authorize the action. These coordination activities range from sharing information ${ }^{345}$ to forming joint fact-finding missions. ${ }^{346}$ In addition, some secretariats even negotiate Memoranda of Understanding with other bodies, ${ }^{347}$

ooperation.pdf?1395762968_(demonstrating the collaboration between convention secretariats to coordinate harmonization and synergy projects through biodiversity-related conventions and related mechanisms); UNEP, Prague Declaration on Enhancing Cooperation among Chemicals-Related Multilateral Environmental Agreements (2004), available at http:/ / ozone.unep.org/Publications/ MP_Handbook/Section_3.8_Annexes_Declarations/Prague_Declaration.shtml, reproduced in Meeting Of the Parties, UNEP, Report of the Executive Director to the Sixteenth Meeting of the Parties to the Montreal Protocol, U.N. Doc. UNEP/OzL.Pro.16/2, Annex V (Sep. 13, 2004), available at http://montrealprotocol.org/new_site/en/meeting_documents.php?mdt_id=1\&m_id=15; COP Convention on Biological Diversity, Report of the Conference of the Parties to the Convention on Biological Diversity on the Work of Its Ninth Meeting, IX/27: Cooperation among Multilateral Environment Agreements and Other Organizations, U.N. Doc UNEP/CBD/COP/DEC/IX/27, ann. I, 193 (Oct. 9, 2008), available at http:// www.cbd.int/doc/decisions/cop-09/cop-09-dec-27en.pdf.

345 See Protocol on Water and Health to the 1992 Convention on the Protection and Use of Transboundary Watercourses and International Lakes, art. XXXVII(5)(a), opened for signature June 17, 1999 - June 18, 2000, 2331 U.N.T.S. 202 (adopted June 17, 1999), available at http://www.unece.org/fileadmin/DAM/ env/documents/2000/wat/mp.wat.2000.1.e.pdf [hereinafter Transboundary Watercourses Convention] (stating the Secretariat's function the transmission to the Parties of reports and other information received in accordance with the provisions of the Protocol); Report of the Meeting of the Parties to the Protocol on Water and Health to the Convention on the Protection and Use of Transboundary Watercourses and International Lakes on Its First Meeting, Decision I/ 2 - Review of Compliance, July 3, 2007, ESCOR, U.N. Doc. ECE/MP.WH/2/Add.3, EUR/06/5069385/1/Add.3, ann. 9, available at http://www.unece.org/fileadmin/ DAM/env/documents/2007/wat/wh/ece.mp.wh.2_add_3.e.pdf (for example, the Committee may transmit information to the secretariats of other international environmental agreements for consideration); Resolution Conference 11.3, available at http://www.cites.org/eng/res/all/11/E11-03R15.pdf (listing several functions of the Secretariat, including requesting information and offering advices).

346 See Joint Mission of the Expert Team of the European Commission and International Conventions to the 'Bystroe Project' in the Ukrainian Part of the Danube Delta, Mission Report of the Expert Team (Nov. 17, 2004), available at http://ec.europa.eu/environment/enlarg/bystroe_docs/ bystroe_joint_mission_ report.pdf (describing the responsibilities of the parties to obtain information).

347 For examples of memorandum of understanding and cooperation between secretariats, see, e.g., Memorandum of Understanding among the Secretariat of the Basel Convention, on the Control of Transboundary Movements of Hazardous Wastes and Their Disposal (SBC) and the Secretariat of the Vienna Convention for the Protection of the Ozone Layer and the Montreal Protocol on Substances that Deplete the Ozone Layer (the Ozone Secretariat) and the Secretariat of the Convention on International Trade in Endangered Species of Wild Fauna and Flora (CITES) (Apr. 26, 2002), available at http://www.cites.org/common/disc/sec/ CITES-BASEL-OZONE.pdf (the Secretariats will jointly draft and implement measures to improve collaboration and information between their Competent 
although these instruments are usually considered non-binding and some even expressly exclude legal effect. ${ }^{348}$ Furthermore, there are small numbers of secretariats that can negotiate administrativebinding international agreements. ${ }^{349}$ To some degree, this issue will only be relevant if the ATT Secretariat is not housed in the Secretariat of an existing international organization. If it were, then the host organization could enter into any necessary agreements, but it was not then its capacity would be an issue.

Authorities); Memorandum of Cooperation Between Agencies to Support the Achievement of the 2010 Biodiversity Target (Sept. 15, 2006), U.N.E.P. No. 59516 , available at http://www.cbd.int/doc/agreements/agmt-hoetf-cites-2006-10-15moc-web-en.pdf (demonstrating the collaboration between international agencies to achieve biological diversity); Memorandum of Cooperation between the Secretariat of the Convention on Biological Diversity and the Secretariat of the International Treaty on Plant Genetic Resources for Food and Agriculture, (Oct. 28, 2010) (noting this memorandum is between the Secretariat of the Convention on Biological Diversity and the Secretariat of the International Treaty on Plant Generic Resources for Food and Agriculture); Memoranda of understanding and cooperation with other conventions and international organizations, The Ramsar Convention on Wetlands, May 27, 2013 available at http://www.ramsar.org/cda/ en/ramsar-documents-mous/main/ramsar/1-31-115_4000_0_; (creating an understanding with other societies); Memorandum of Understanding between the Secretariat of the Pacific Regional Environment Programme and the Secretariat of the Convention on Biological Diversity (Feb. 16, 2009), available at http:/ / www.cbd.int/doc/agreements/agmt-sprep-2009-02-16-mou-web-en.pdf (demonstrating collaboration between the Secretariat of the Pacific Regional Environment Programme and the Secretariat of the Convention on Biological Diversity within specific geographical areas).

348 For examples of agreements that are binding see, e.g., Memorandum of Understanding between CCAMLR and WCPFC, Arrangement between The Commission for the Conservation and Management of Highly Migratory Fish Stocks in the Western and Central Pacific Ocean and The Commission for the Conservation of Antarctic Marine Living Resources Annex 6 (Nov. 2008) (specifically stating that the Arrangement does not create legally binding obligations); Commission for the Conservation of Antarctic Marine Living Resources, Report of the Twenty-Eighth Meeting of the Commission, Report SC-CAMLR-XXVIII, ann. 8, Memorandum of Understanding between CCAMLR and ACAP (Nov. 2009) (the MOU is not legally binding between participants).

349 See, e.g., Chemical Weapons Convention, supra note 17, at art. VIII (D)(39) ("The Technical Secretariat shall Negotiate agreements or arrangements relating to the implementation of verification activities with States Parties, subject to approval by the Executive Council"); Test-Ban Treaty, supra note 11, at art. II(D) (43) (granting the authority to make and "approve" arrangements with

States Parties, other States and international organizations"); Biodiversity Convention, supra note 11, at art. 24(1)(d) (the Secretariat's functions include entering into administrative and contractual arrangements as may be required for the effective discharge of its functions). 


\section{LEGAL EFFECT OF ACTS}

Following from the powers of the new ATT treaty regime, the next question would be the legal effects of its organs' activities. Some arms control treaties, especially those that do not create a CSP, explicitly permit resort to the UNSC for investigation and/or enforcement of the treaty. ${ }^{350}$ This explicit provision is probably not necessary since the underlying obligations themselves, where they threaten peace, should already be a topic that could seize the UNSC. This section is not concerned with the possibility of enforcement of international legal obligations through normal international legal means, but rather the legal effect of the acts of the CSP itself.

The types of decisions that CSPs can reach are quite varied. Some decisions are designated "resolutions," "recommendations," "decisions," or other names, and those designations might suggest differing legal value. ${ }^{351}$ The temptation is to find meaningful normative distinctions between these types, but there is little uniformity or guidance in this matter.

\subsection{Not binding}

The usual understanding for CSPs is that their decisions, whether they are called recommendations or decisions, or something else, are not legally binding, 352 but that does not mean that these views are not contested. 353 Fitzmaurice and Merkouris

350 See Biological Weapons Convention, supra note 184, at art. VI (stating that any State Party to the Convention may lodge a complaint with the UNSC should it find that any other State Party is acting in breach of its obligations).

351 See, e.g., Ramsar Convention, supra note 9, at art. 6 (stating that the Contracting Parties shall meet as the needs arise in an advisory capacity).

352 For examples of conventions that present decisions as less than legally binding see, e.g., Inter-American Trafficking Convention, supra note 43, at art. XX(2) ("Decisions of the Consultative Committee shall be recommendatory in nature"); Cluster Munitions Convention, supra note 7, at art. 8 (the State Parties are limited to making clarifications and recommendations to other State Parties in order to facilitate compliance with the obligations of the Convention); Natural Res. Def. Council v. Envtl Prot. Agency, 464 F.3d 1, 1 (D.C. Cir. 2006) (holding that EPA rule was sufficient injury in fact for standing, and Montreal Protocol were not "law" within the meaning of the Clean Air Act and were not enforceable in federal court).

353 See, e.g., R. Churchill \& G. Ulfstein, supra note 54, at $641-42$ (discussing the importance of COP's interpretation of the provisions of MEAs); Malgosia Fitzmaurice, Dynamic (Evolutive) Interpretation of Treaties, Part II, 22 HAGUE Y.B. 
argue that CSP decisions could be understood to be simply another means of state consent to treaty obligations, as states are free under the Vienna Convention on the Law of Treaties to establish the manner of their consent, 354 but that view necessitates that CSP decisions be assimilated to treaties. It has alternatively been suggested that the doctrine of implied powers alone might result in the legally binding nature of decisions of the CSP, 355 but this conclusion is difficult to sustain since the legally binding nature of the decision would have to be the necessary intendment of the parties. Given the lengthy experience of the international community with treaties creating CSPs, one might expect such a provision to now be explicit if it were intended to be granted. In any analysis, the phenomenon is clearly highly flexible and informal regarding law.

\subsection{Explicitly binding}

It is generally understood that, even where the treaty permits the CSP to adopt measures against states for non-compliance, that the legally binding effect would need to be explicit, or the measures would be considered non-binding. ${ }^{356}$ Thus in some cases, the treaty

INT'L L. J. 4 (2009) (discussing the evaluative interpretations and legislative techniques based on multilateral environmental agreements, and the implied power of the organs of the MEAs); Jutta Brunnée, Reweaving the Fabric of International Law? Patterns of Consent in Environmental Framework Agreements, in RÖBEN EDS DEVELOPMENTS OF INTERNATIONAL LAW IN TREATY MAKING 101 (Rüdiger Wolfrum \& Volker Röben eds., 2005) (analyzing multilateral environmental agreements, and highlighting shifting patterns of consent, intertwined with subtle but significant shifts of decision-making from the States Parties to an MEA to its Conference of the Parties).

354 See M. Fitzmaurice \& P. Merkouris, Uniformity versus Specialization (1): The Quest for a Uniform Law of Inter-State Treaties, in RESEARCH HANDBOOK ON THE LAW OF TREATIES (C. Tams et al. eds., 2014) (providing an overview of the genesis and life of a treaty, and analyzing the existence of a characteristics of uniformity of the relevant provisions amongst inter-State treaties).

355 See R. Churchill \& G. Ulfstein, supra note 54, at 633-34 (discussing the application of international institutional law and its implied power).

356 See Exec. Body for the Convention on Long-range Transboundary Air Pollution, Rep., 15th Sess., Dec. 16-19, 1997, U.N. Doc. ECE/EB.AIR/53, para. 48 (Jan. 7, 1998), available at http://www.unece.org/env/lrtap/executivebody/eb_ decision.htm (“[T]he Executive Body's decisions concerning compliance were not legally binding unless a provision in the protocol in question rendered them so"); Kyoto Protocol, supra note 11, art. 18 ("The provisions of Article 14 of the 
provides that decisions of the CSP are legally-binding, 357 but other substantive decisions are not, such as the rules for emissions trading under the Kyoto Protocol. 358 Some CSPs are empowered to amend the treaty or issue decisions similar to regulations; whereas others establish "enabling clauses," authorizing the CSP to adopt rules further elaborating on the obligations in the treaty. ${ }^{359}$ Where this power to bind exists, courts have recognized that the decisions would have legal effect. ${ }^{360}$ This is not the case with the ATT.

\subsection{Clarifying the treaty}

Another way that the decisions of the CSP might be legallybinding is where the CSP alters the treaty text through amendment or simply alters an annex of scheduled items. These alternatives have been discussed above.

A further possibility is for the CSP to adopt decisions clarifying or providing more detail for existing obligations. In other contexts, these nominally decisions have been seen to have binding effect. ${ }^{361}$ The Court of Appeals for the Washington, D.C. Circuit in the Natural Resources Defense Council case suggested that the decisions of the CSP would at least be strong indications of the meaning of the treaty,

Convention on settlement of disputes shall apply mutatis mutandis to this Protocol.").

357 See Bonn Convention, supra note 11, at art. 17 (providing procedure for when amendments shall enter in force).

358 See Kyoto Protocol, supra note 11, at art. 17 (stating that the Conference of the Parties has an obligation to define the relevant principles, modalities, rules and guidelines - in particular for verification-reporting, and accountability pertaining to emissions trading).

359 See Montreal Protocol, supra note 11, at art. 8 (authorizing CSP to adopt procedure and mechanisms for assessing compliance with the treaty's obligations, with more specificity than the more vague treaty terms).

360 See Natural Res. Def. Council v. Envtl Prot. Agency, 464 F.3d 1, 10 (D.C. Cir. 2006) (holding that the EPA rule was sufficient injury in fact for standing but the Montreal Protocol was not "law" within the meaning of the Clean Air Act; therefore, the rule was not enforceable in federal court).

361 See e.g. U.N.G.A. Res. 2323 (XXII), 22d Sess., 1635th plen. Mtg., (Dec. 18, 1967) (urging states to adhere to the Convention on the Privileges and Immunities of the U.N.); U.N. Doc. A/C.6/385 (U.N. legal counsel arguing before the Sixth Committee that the Convention was merely clarifying the immunities of the U.N., so the Resolution bound states to the Convention regardless of adherence). See also Montreal Protocol, supra note 11, at art. 2(9) (authorizing the COP to adopt changes to the binding ozone-depleting substances allowances). 
but only where the treaty was vague. ${ }^{362}$ Wiersema argues, however, that the decision in that case created new obligations and did not simply clarify existing ones. ${ }^{363}$ She points to the Lac Wetland case as possible guidance. ${ }^{364}$ In this case, the Dutch Government adopted the view that the decisions ("resolutions" and "recommendations") of the CSP about the Ramsar Convention are to be treated as having a binding legal effect. ${ }^{365}$ The reason behind such undertaking was that the Ramsar Convention was deliberately vague on the part of its obligations and that the CSP was created to clarify such commitments. ${ }^{366}$ That conclusion by the Dutch Government is not entirely satisfactory. The CSP decided that parties must perform environmental impact studies, which does not appear to be directly clarifying any particular treaty provision. Be that as it may, it appears that in areas in which substantive obligations of the ATT remain unclear, the CSP may have a role, following the emerging practice of CSPs generally, to clarify or supplement the existing obligations.

\subsection{Establish criteria for compliance}

In addition to the power to make substantive changes to the text of the treaty, the CSP often has a significant role in determining the format, the means and methods of implementing any obligations under the relevant treaty. This power is especially important for determining the criteria used for deciding which items to list. ${ }^{367}$ The

362 NRDC, 464 F.3d at 9 ("The 'decisions' are useful only to the extent they shed light on ambiguous terms in the Protocol.").

363 See A. Wiersema, The New International Law-Maker? Conferences of the Parties to Multilateral Environmental Agreements, 31 MiCH. J. INT’L L. 231 (2009) (arguing that certain ruling have resulted in more ambiguity than before).

364 See id. (citing Jonathan M. Verschuuren, Ramsar Soft Law Is Not Soft at All, available at http://www.ramsar.org/pdf/wurc/wurc_verschuuren_bonaire.pdf) (translating and summarizing the Netherlands Crown Decision of 11 September 2007).

365 Id.

366 See generally id.

367 See M.J. Bowman, The Ramsar Convention Comes of Age, XLII NETH. INT'L L. REV. 1 (1995), available at http://archive.ramsar.org/cda/en/ramsar-documentswurl-laws-ramsar-convention-in-20942/main/ramsar/1-31-116-165\%5E20942_ 4000_0_ (providing example of establishing criteria). 
CSPs have also developed guidance on listing. ${ }^{368}$ Some of these articles appear quite innocuous since they only lay down reporting or monitoring mechanisms ${ }^{369}$ but they can have significant impact on the operation of the treaty. ${ }^{370}$

The precise details of reporting obligations will not be discussed in this article, but for purposes of the discussion on the powers of the CSP, it is noteworthy that the ATT only requires minimal content in the report. ${ }^{371}$ Since the ATT calls for a significant amount of information over a range of topics, reports may differ from each other in terms of scope and structure.372 Presumably, the States Parties will want to be able to easily access and compare information in the reports, so a wise solution is to have a reporting template. ${ }^{373}$ As discussed above under the powers of the Secretariat, the CSP could develop such templates or the Secretariat could (perhaps to be later adopted by the CSP), or they could even be developed by the

368 See e.g., Conference of the Parties to the Convention on Wetlands (Ramsar, Iran, 1971), 8th mtg., Nov. 18-26, 2002, Additional Guidance for Identifying and Designating Under-Represented Wetland Types as Wetlands of International Importance, Res. VIII.11 (highlighting and elaborating on certain points); Conference of the Parties to CITES, June 3-15, 2007, Criteria for amendment of appendices I and II, Conf. 9.24 (Rev. CoP14) (amending Res. Conf. 9.24 (1994)); Kyoto Protocol, supra note 11, at arts. 6, 12, 17 (describing the methods of the agreement).

369 See, e.g., Rev. of Res., Conf. 10.10 (Rev. CoP14), Trade in Elephant Specimens, CoP15 Doc. 18, Annex 7, (requiring regular reports); Rep. of the U.N.F.C.C.C, Implications of Possible Changes to the Limit for Small-Scale Afforestation and Reforestation Clean Development Mechanism Project Activities, U.N. Doc. FCCC/KP/CMP/2007/9/Add.1 (Mar. 14, 2008) (discussing previous reporting).

370 See, e.g., Enhancing the Information on Wetlands of International Importance (Ramsar Sites), Res. VIII.13, Conference of the Contracting Parties to the Convention on Wetlands, 8th mtg., Nov. 18-26, 2002(detailing aspects with requests and suggestions).

371 See ATT art. 13(1) (stating "national laws, national control lists, and other regulations implementing the treaty"). See also id. at art. 13(3) (stating that the report "may contain the same information submitted by the State Party to relevant United Nations frameworks, including the United Nations Register of Conventional Arms. Reports may exclude commercially sensitive or national security information.").

372 The initial reports under the U.N. Program of Action that were not comparable with each other until a standardized template was adopted. See P. Holtom, and M. Bromley, Implementing an Arms Trade Treaty: Lessons on Reporting and Monitoring from Existing Mechanisms, SIPRI Policy Paper No. 28 (July 2011), available at http://books.sipri.org/files/PP/SIPRIPP28.pdf (last visited Mar. 29, 2015).

373 See S. Bauer, P. Beijer \& M. Bromley, supra note 39, at 3 (describing the various frameworks for reporting under a convention or treaty). 
preparatory meetings for CSP (perhaps again for adoption by the CSP).

Thus there is considerable room for the CSP to clarify and add explanations to the articles of the treaty without the need to alter the specific language. For example, the CSP may not require the inclusion of commercially sensitive or national security information, but it could commercial sensitivity that is used in any requirement. Also as discussed above, the CSP and/or the Secretariat may, after consultation with other entities, require a reporting template that is harmonized with other reporting regimes.

\subsection{Internal decisions}

Where the treaty is silent, we can apply the normal principle of international institutional law that "internal" decisions (i.e. decisions regarding internal governance) are binding. ${ }^{374}$ Ulfstein argues that "substantive law-making" power by the CSP, such as altering the obligations on the parties, can be limited by the constitutive instrument but "internal law-making", such as providing internal rules of operation, does not have the same limitation. ${ }^{375}$ Thus, for example, decisions governing the Secretariat and its budget would be binding. Similarly, decisions governing the creation and operation of subsidiary bodies must be seen as binding on those bodies. ${ }^{376}$ Aside from these decisions, all other decisions should not be presumed as binding.

\subsection{External decisions}

Furthermore, there is nothing in the treaty that specifies the binding force of the CSP's findings in reviewing implementation,

\footnotetext{
374 For arguments of why internal agreements are not binding see C.F. Amerasinghe, supra note 52, at 192 SCHERMERS \& BLOKKER, supra note 19, at \$744.

375 Geir Ulfstein, Comment on Reweaving the Fabric of International Law? Patterns of Consent in Environmental Framework Agreements, in DEVELOPMENTS OF INTERNATIONAL LAW IN TREATY MAKING 145-6 (R. Wolfrum \& V. Röben eds., 2005).

376 See Eleventh Meeting of the Conference of the Parties to CITES, Gigiri, Kenya, Apr. 10-20, 2000, Conf. 11.1: Establishment of Committees, Rev. CoP14, amended by Fourteenth Meeting of the Conference of the Parties to CITES, The Hague, Neth., June 3-15, 2007, CITES Strategic Vision: 2008-2013, Res. 14.2 (establishing committees and specifying their general terms of reference).
} 
regardless of whether those findings are considered enforcement decisions or not. This omission can be contrasted with the Kyoto Protocol where it clearly states that compliance decisions "entailing binding consequences shall be adopted by means of an amendment to this Protocol." 377

As for the discussion on the powers of the CSP, some of the negotiating states not only envisioned a stronger mechanism for review in terms of powers, but also perhaps in terms of legal effect. Algeria, for example, suggested that the CSP may have the power to take "action against a State," 378 although it is unclear what legal effect this proposal was meant to have. In any event, this suggestion was not adopted in the final draft of the treaty. Based on the preference for weaker powers in the area of consultations and cooperation, and the clear distinction between the CSP's duties and amendment of the ATT, the legal effect was likely intended to be very limited.

\subsection{Subsequent agreement/practice}

A further consideration is whether decisions of the CSP could be treated as a "subsequent agreement" 379 or "subsequent practice" of the parties within the meaning of the VCLT. 380

The VCLT provides that "subsequent agreements" 381 between the parties shall be taken into account in interpreting the terms of the treaty. ${ }^{382}$ Practice on applying this provision of the VCLT does not exclude treaty regimes addressing arms-control. ${ }^{383}$ Subsequent agreements, although not specifically amending the treaty, can change the legal relationships between the parties and can amount to, de facto, treaty amendments. Since there does not appear to be any required form for a subsequent agreement, and the word "agreement" has a broader meaning than "treaty," we can consider

377 Kyoto Protocol, supra note 11, art. 18.

378 U.N. Secretariat, Compilations of views, May 14, 2012 (response of Alg., para. 5, Mar. 29, 2012).

379 VCLT, supra note 61, at art. 31(3)(a).

380 Id. at art. 31(3)(b).

381 Id.

382 Id.

383 Biological Weapons Convention, supra note 184, at part II 
that the agreements of the States Parties to the ATT could inform our understanding of the treaty text. 384

The meaning of the term "agreement" has been widely interpreted to include resolutions as well as guidelines adopted by parties to the treaty. ${ }^{385}$ However, it is generally understood that while acts resulting from tacit acceptance do not amount to "subsequent agreements", they can nonetheless contain an interpretation of the treaty. ${ }^{386}$ In some treaty regimes, it would appear that a qualifying "subsequent" or "additional" agreement must be adopted in the context of a review conference ${ }^{387}$ rather than a CSP. ${ }^{388}$ In the context of the WTO, the appellate body has, on

384 See Daniel H. Joyner, INTERPRETING THE NuCLEAR NON-PROLIFERATION TREATY 83 (2011), available at http://journals.cambridge.org/action/ displayAbstract?fromPage $=$ online \&aid $=8896498 \&$ fileId $=$ S0165070X1200109X; Anthony Aust, MODERN TREATy LAW AND PRACTICE 213-214 (2d ed. 2007), available at http://www.academia.edu/4376372/Anthony_Aust_-_Handbook_of_ International_Law_2nd_edition (relying on various agreements to provide context to the convention).

385 See International Maritime Organization Sub-Division of Legal Affairs, Agenda item 4 (Ocean fertilization), Doc. LC 33/J/6, para. 3 (stating that " $[\mathrm{t}$ ]his seems to indicate that, provided its intention is clear, the interpretation could take various forms, including a resolution adopted at a meeting of the parties, or even a decision recorded in the summary records of a meeting of the parties"); Montreal Protocol Fifteenth Meeting of the Parties, Dec. XV/3, Doc. UNEP/OzL.Pro.15/9, chap. XVIII.A (describing obligations of the parties under amendments to the protocol).

386 For provisions detailing how the body is to be examined see IMO, Sixteenth Consultative Meeting of the Contracting Parties, Res. LC.50 (16), Annex 4, Res. LC.51 (16), Annex 5,; IMO, Res. LDC.41 (13), para. 1; IMO, Dumping at sea: the evolution of the Convention on the Prevention of Marine Pollution by Dumping of Wastes and Other Matter (LC), 1972, FOCUS ON IMO (July 1997).

387 See Whaling in the Antarctic (Australia v. Japan.: New Zealand Intervening), I.C.J., para. 46 (Mar. 31, 2014), available at http://www.icj-cij.org/ docket/files/148/18136.pdf ("[R]ecommendations, which take the form of resolutions, are not binding. However, when they are adopted by consensus or by a unanimous vote, they may be relevant for the interpretation of the Convention or its Schedule."); Biological Weapons ISU, Additional agreements reached by previous Review Conferences relating to each article of the Convention, Doc. BWC/CONF.VII/INF.5 (including an update to the understandings and agreements reached by that Conference, Geneva 2012).

388 See, e.g., Framework Convention on Tobacco Control, arts. 7, 9; COP, Framework Convention on Tobacco Control, Intergovernmental Negotiating Body on a Protocol on Illicit Trade in Tobacco Products, Revised Chairperson's text on a protocol on illicit trade in tobacco products, and general debate: legal advice on the scope of the protocol, Note by the WHO Legal Counsel Doc. FCTC/COP/INBIT/3/INF.DOC./6,; R. Churchill \& G. Ulfstein, supra note 54, at 639; Brunnée, supra note 354, at 110-15; S.F. Halabi, The World Health Organization's Framework 
multiple occasions, treated the decisions of the Ministerial Conference as agreements of the States Parties. ${ }^{389}$ Of course, this conclusion would require the consent of all of the States Parties.

This same understanding has also been applied to CSPs, 390 and may have been part of the reasoning behind the ruling of the International Court of Justice in the Whaling in the Antarctic case. ${ }^{391}$ Returning to the discussion on the Lac Wetland case, it is still unclear as whether the Dutch Crown had actual evidence of a unanimous vote or whether it conflated consensus with unanimity. The difficulty here lies in distinguishing these agreements from those undertaken by the Review Conference as amendments to the treaty. It seems strange to carefully vest the Review Conference with the authority to amend the treaty while casually permit the CSP to adopt subsequent agreements with similar effect.

Some commentators and at least one case suggest that interpretations of the treaty and other decisions by the CSP should be considered "subsequent practice" by the States Parties. Article $31(3)(b)$ of the VCLT states that it shall be taken into account, together with the context "[a]ny subsequent practice in the application of the treaty which establishes the agreement of the parties regarding its interpretation" .392

In the ICJ cases, the court found that practice had effectively modified the underlying treaties, however both cases concerned internal decision-making processes of U.N. organs. The ICJ has recently held that decisions of treaty bodies on substantive obligations do not necessarily occur with the consent of all States Parties, and thus not all decisions can be treated as subsequent agreements or practice. ${ }^{393}$ But that was not the case in the past, where subsequent practice has created new external obligations. ${ }^{394}$

Convention on Tobacco Control: an analysis of guidelines adopted by the Conference of the Parties, 39 GEO. J. INT'L \& COMP. L. 14-16 (2010).

389 For examples of how a judicial body may use an agreement to a convention to imply an pact among the participating state see, e.g., US - Clove Cigarettes, Appl. Body Report, paras. 267-68 ("WTO Appl. Body"); EC - Bananas III, Second Recourse to Article 21.5, Appl. Body Report, para. 388 (WTO Appl. Body).

390 See, e.g., R. Churchill \& G. Ulfstein, supra note 54, at 641; Verschuuren, Ramsar Soft Law Is Not Soft at All, supra note 365, at 2 (discussing the Lac Wetland case).

391 Whaling in the Antarctic, 2014 ICJ Reps., supra note 298, para. 83.

392 VCLT, supra note 61, at art 31(3)(b).

393 Id.

394 See infra note 307. 
Here the GATT is instructive. Initially the GATT was a treaty without an accompanying international organization, but over time and practice, an ad hoc, de facto organization grew up around the treaty. 395 The GATT body then created new rules and altered existing ones in the GATT through practice. ${ }^{396}$

Much of the foregoing applies equally to subsidiary bodies. Again, under general principles of international institutional law, the subsidiary bodies should not enjoy greater power than the principal organ. ${ }^{397}$ Thus, if the CSP cannot legally bind the States Parties, then the subsidiary organs cannot do it as well.

\subsection{Obligation to cooperate}

Some treaties creating CSPs include legally binding obligations on the parties to cooperate with the CSP, for example in consultations on implementation and reporting. ${ }^{398}$ In this case, the CSP is the supreme body of the treaty and is given an explicit mandate to direct the activity of the Secretariat and other subsidiary bodies in whatever way it deems fit for a better implementation of the treaty. 399

In keeping with this practice, the ATT contains explicit obligations to report, 400 though it is important to note that some of the reporting duties are not mandatory. 401 But those are obligations arising from the treaty itself, not from the decisions of the CSP. After all, these types of explicit obligations to report or cooperate exist

395 See infra note 307.

396 Decision of the Contracting Parties, Differential and More Favorable Treatment Reciprocity and Fuller Participation of Developing Countries (Nov. 28, 1979), B.I.S.D. (26th Supp.) 203 (1980).

397 SCHERMERS \& BLOKKER, supra note 19 , at $\$ 225$.

398 See Test-Ban Treaty, art. II(A)(5) (requiring each party to cooperate with the organization). See also UNFCCC, supra note 11, at art. 12 (binding the parties to obligations).

399 See UNFCCC, supra note 11, at arts. 7-10. See also Anti-Personnel Mines Convention, supra note 7, art. 8(7)-(15), 8(18) (providing for investigation).

400 See ATT, supra note 1, arts. 11(6), 13 (explaining the measures to be applied with regards to diversion in art. 11(6) and stating the measures implemented in art. 13). report).

401 See, e.g., id. at arts. 13(2),(16) (encouraging, but not obligating parties to 
even where a CSP is not being created. ${ }^{402}$ The ATT also contains obligations to cooperate. ${ }^{403}$

These kinds of cooperation obligations are normal and need not be explicit, arising already from pacta sunt servanda. ${ }^{404}$ This principle appears in, inter alia, VCLT, article 26, which states that "[e]very treaty in force is binding upon the parties to it and must be performed by them in good faith," 405 but the wording of the obligations suggests that the obligation to cooperate is owed to other States Parties, not necessarily to the CSP as such. One view on such wording would be to see the CSP as the cooperation mechanism implicit in the general obligation to cooperate. Thus, the member states may cooperate within the CSP, but this does not necessarily mean that such must cooperate with the CSP.

However, drawing on principles of international institutional law, even when a constitutive instrument is silent on the duty to cooperate with the institution, the obligation is implied. 406 It would appear that binding decisions could be binding in the cases where the state party consents to binding force, ${ }^{407}$ where the state abuses its legal rights and loses its right to refuse to comply, ${ }^{408}$ or where the state is bound by estoppel based upon its subsequent acts in compliance with the decision that other states rely on. ${ }^{409}$ To the

402 See, e.g., Biological Weapons Convention, supra note 184, at art. (V) (instructing States Parties of the Convention to consult one another and cooperate in solving problems that arise in relation to the objectives of the Convention and also states, "[c]onsultation and cooperation pursuant to this article may also be undertaken through appropriate international procedures within the framework of the United Nations and in accordance with its Charter").

403 See ATT, supra note 1, art. 15(1) (obligating parties to cooperate consistent with their respective security interests and national laws).

404 See VCLT, supra note 61, at art. 26.

405 See also A. Aust, supra note 385, at 179-80(noting that the principle of pacta sunt servanda is regarded as "the fundamental principle of the law of treaties").

406 For examples of where a duty to cooperate can be implied see Voting Procedure on Questions Relating to Reports and Petitions Concerning the Territory of South-west Africa, Adv. Op. 1955 ICJ Reps. 67, 118-19 (Lauterpacht) (June 7) ("Voting Proc. Case"); Interpretation of the Agreement of 25 March 1951 between the WHO and Egypt, Adv. Op., ICJ Reps. 73, 93, 95, 96, 97 (Dec. 20, 1980); Whaling in the Antarctic, 2014 I.C.J. Reps. para. 83.

407 See, e.g., Treaty of Peace with Italy (agreeing to accept a UNGA recommendation as binding).

408 See Voting Proc. Case, 1955 ICJ Reps. 120 (Lauterpacht) (explaining how the abuse of right might make a recommendation binding.

409 See Georg Schwarzenberger \& E. D. Brown, A MANUAL OF INTERNATIONAL LAW (6th ed. 1976)(requiring the party to cooperate based on implied agreement through previous actions). 
degree that the subsequent agreement argument above would fail, the estoppel argument might alternatively explain why the authorities in some cases inquired whether the state had voted in favor of the decision by the treaty body in the first place. ${ }^{410}$ Voting in favor of a decision might lead other states to rely on the voting state's assurance that it would act accordingly.

\subsection{Customary international law}

Yet another means by which the acts of the CSP may take on binding legal effect is through the normal operation of customary international law. Provided that there is widespread and consistent state practice and opinio juris, ${ }^{411}$ some customary norms may emerge. The ICJ has already recognized that customary law may arise from a treaty regime, and even more on point may be evidenced by the decisions of international organizations, 412 though that latter understanding appears limited to the UNGA. Extensive discussion on this possibility will be omitted.

\subsection{Soft law}

In the alternative to "hard" customary international law, and considering the use of the term "recommendations," some authors have suggested that the decisions adopted by a CSP could amount to "soft law." 413 Soft law is based on the argument that the full

410 See Verschuuren, Ramsar Soft Law Is Not Soft at All, supra note 278, at 2-5 (describing how a judicial body used one sovereign's compliance with an agreement as sufficient evident to imply agreement).

411 See N. Sea Cont. Shelf cases (Germ. v. Den.; Germ. v. Neths.), Judgment, 1969 ICJ REPS. 44 (showing how it is somewhat unclear whether the CSP decisions may be treated as practice or opinio juris, or even both).

412 See Legality of the Threat or Use of Nuclear Weapons, Adv. Op., 1996 ICJ Reps. 226, paras. 70-71(“[UNGA resolutions] can, in certain circumstances, provide evidence important for establishing the existence of a rule or the emergence of an opinio juris.").

413 For an examination of the actual benefits of certain international laws See, e.g., Brunnée, supra note 267, at 118-23; CITES COP, CITES Guidelines for Transport and Preparation for Shipment of Live Animals and Plants, Doc. Plen. 2.6 (Rev.), item XIX (1980); Consultative Meeting of the Parties to the London Convention that call for a moratorium on the dumping of radioactive waste (1983 and 1985); Ramsar COP Recomm. 2.3, Doc. C.4.12 (1984). 
magnitude and variability of legal effect cannot be explained adequately with the usual binary law/non-law system. ${ }^{414}$

For purposes of this article, we can simply observe that even if the decisions of the CSP would not have the typical "hard law" legal effect under any of the means described above, they would surely have some political consequences. ${ }^{415}$ This conclusion was precisely the opinion of the court in the National Resources Defense Council case. ${ }^{416}$ Along with claims to form hard law, the CSP will probably have some ability to shame non-complying states. ${ }^{417}$

\subsection{Countermeasures}

Lastly, even if there is no legal effect from certain CSP decisions, there is the possibility that states might want to impose sanctions or countermeasures on states that do not comply with the ATT. This step of imposing sanctions might or might not be preceded by a CSP finding of non-compliance, assuming for the moment that the CSP can issues such findings.

It could be that the ATT provides the only sanctions possible, though it is remarkably silent on the matter. On the other hand, it could be that general international law continues to apply so that other states would have the power to impose countermeasures in cases of non-compliance. For the purposes of this article, the author will continue to apply international institutional law insofar as the CSP functions as an institution.

Furthermore, any material breach of the ATT in the sense of article 60 of the VCLT may also permit not only countermeasures in case of non-compliance, but also suspension or termination of the ATT. Again, this article applies international institutional law from a functional perspective, and thus suspension or termination in case

414 For a discussion on the confusion surrounding the secondary effects of international law See, e.g., O. Schachter, Towards a Theory of International Obligation, in THE EFFECTIVENESS OF INTERNATIONAL Decisions 9 (Stephen M. Schwebel ed., 1971); R.Y. Jennings, What Is International Law and How Do We Tell It when We See It?, 37 SCHWEIZERISCHES JAHRBUCH FÜR INTERNATIONALES RECHT 59 (1981)

415 See generally R. Churchill \& G. Ulfstein, supra note 54, at 641; Brunnée, supra note 267 , at 111). 2006)

416 Natural Res. Def. Council v. Envtl Prot. Agency, 464 F.3d 8-10 (D.C. Cir.

417 See Montreal Protocol MOP Dec. VIII/24, Doc. UNEP/OzL.Pro8/12 (1996) (giving the CSP the ability to issue public statements regarding member states). 
[Vol. 36:4

of material breach would be unlikely. Institutional law contemplates cooperation continuing after breach. ${ }^{418}$

\section{PRIVILEGES AND IMMUNITIES}

In keeping with the unclear nature of the CSP as an international organization, a treaty organ without legal personality, or a quasiorganization, it is also unclear whether the CSP and its employees and agents will benefit from privileges and immunities. Generally, international organizations and the persons that undertake activities on behalf of such organizations benefit from privileges and immunities limited to their official acts, ${ }^{419}$ the well known as "functional immunity." 420

Whether a regime has privileges and immunities is linked to the question of the legal personality of the regime, and whether or not the organ is an international organization. That being said, there are some exceptions where certain states may grant immunities to important international NGOs, ${ }^{421}$ but in general, where the organ is lacking personality, the members would bear reasonability for the actions of the CSP.422

The representatives to the CSP may benefit from personal and/or functional immunity as state officials, such as Heads of States, Heads of Government or Foreign Ministers, and perhaps

418 See SCHERMERS \& BLOKKER, supra note 19, at $§ 866$ (discussing provisions controlling the post-breach actions).

419 For discussions of the incentives of various privileges and immunities See, e.g., Branno v Ministry of War (Ct. Cass., Ital.) reprinted at 22 INT'L L. REPS. 756-57; Iran-US Claims Trib. v A.S. (Sup. Ct., Neths.) reprinted at 94 INT'L L. REPS. 321-30.

420 August Reinisch, INTERNATIONAL ORGANIZATIONS BEFORE NATIONAL COURTS 206 (2000).

421 See, e.g., The Global Alliance for Vaccines and Immunizations, Hosting transition update, 2, available at (http://www.google.com/url?sa=t\&rct=j\&q=\& esrc $=$ s\&source $=$ web\&cd $=1 \&$ ved $=0 \mathrm{CB} 8 \mathrm{QFjAA} \&$ url $=$ http $\% 3 \mathrm{~A} \% 2 \mathrm{~F} \% 2 \mathrm{Fwww}$.gavi.o

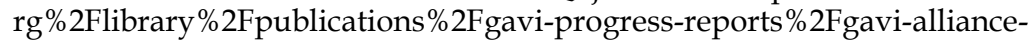
progress-report-2010\%2F\&ei=jtgNVdnJGIbfsAT524LQDg\&usg= AFQjCNGmQGq_W08ueMdsexiLsQEqjYaP5A\&sig2=RHQ1NckBbl7A4KcWCGg QDA\&bvm=bv.88528373,d.cWc) (last visited Apr. 5, 2015) (detailing the acquisition of privileges and immunities under the Swiss Host State Act).

422 See Int'1 L. Comm'n, Giorgio Gaja, SPEC. RAPP., First report on responsibility of international organization, U.N. Doc. A/CN.4/532, 15 (describing the organization overseeing the organ as being ultimately responsible). 
even "other high ranking officials." 423 However, discharge of the CSP functions by officers of this rank is unlikely and, thus, the category left open by the ICJ becomes significant. In addition to personal immunity, the representatives might also have functional immunity by benefit of their role as state officers. Notwithstanding the potential to enjoy immunity deriving from the state they represent, representatives might also enjoy immunity deriving from the CSP.

Some arms-control treaty regime organs have received privileges and immunities that cover the organization (where an organization was created), ${ }^{424}$ delegates to the organization, ${ }^{425}$ staff of the organization, ${ }^{426}$ and even fact-finding experts. ${ }^{427}$ Where the immunities are not in the constitutive instrument, supplementary agreements can grant or clarify the immunities the organs and staff enjoy. ${ }^{428}$ These agreements were always covering the organization (where one is clearly created) or the Secretariat, not the CSP specifically.

However, the UNOLA suggested that the CSP could simply adopt a decision providing for "the required juridical personality and legal capacity upon the Convention Secretariat and according it such privileges and immunities as are necessary for the fulfillment of its purposes." 429 This is similar to the approach of the CSP of the Montreal Protocol in reaching an agreement with the host state for

423 See generally Case Concerning the Arrest Warrant of Apr. 11, 2000 (DR Congo v. Belg.), 2002 ICJ Reps. 1.

424 See, e.g., Test-Ban Treaty, supra note 17, at art. (II)(E)(54)(creating the organization through the privileges and immunities granted by the treaty).

425 See, e.g., id. at art. (II)(E)(55); Preparatory Commission Resolution, art. 22; Chemical Weapons Convention, art. (VIII)(D)(48), (49), Verification Annex, Pt. $\mathrm{II}(\mathrm{B})$ (detailing the privileges of the delegates to the convention).

426 For examples of conventions that detail the privileges granted to the staff see, e.g., Test-Ban Treaty, supra note 17, art. (II)(E)(57); Preparatory Commission Resolution, art. 22; Chemical Weapons Convention, art. (VIII)(D)(48).

427 See, e.g., Anti-Personnel Mines Convention, supra note 7, art. 8(10) (providing procedure for the fact-finding experts).

428 See, e.g., Chemical Weapons Convention, supra note 17, art. (VIII)(D)(50); Agreement Concerning the Headquarters of the Convention Secretariat, June 20, 1996, U.N.-Germany-UNFCCC Secretariat; Agreement Regulating Matters Resulting from the Establishment in Canada of the Multilateral Fund and Its Organs, Nov. 23, 1998, Canada-Montreal Protocol Multilateral Fund (concerning only the fund established by the CSP, not the CSP itself)

429 FCCC Arrangements for relocation 1996, supra note 57 at para. 11(2). 
privileges and immunities for its multilateral fund. ${ }^{430}$ Presumably, if the CSP can grant the Secretariat immunities by simple decision, then the CSP must itself enjoy immunity (or perhaps be able to enjoy immunity by simple decision of the States Parties at a Review Conference). This way it might seem that privileges and immunities are potentially available.

\section{CONCLUSION}

This article has surveyed the practices of several various treaty organs in order to reach an understanding of how international institutional law applies to this relatively recent phenomenon. As a case study, it has looked at the new ATT treaty organs in order to find their place in international institutional law, and comment on the likely application of international institutional law to its organs.

Treaty organs have evolved considerably from their early, primarily bureaucratic, role into significant international actors. Although they might not be true international organizations, and must suffer designation "quasi", they are not completely exempt from the increasingly coherent field of international institutional law. The ATT treaty organs are no exception from such rules and the initial steps towards constituting these organs show every sign that they will fall into the existing mold. Increasingly the "quasi" designation may become more distracting, as we move to the functional application of the corpus of international institutional law.

430 See Report of the Subsidiary Body for Implementation on the Work of Its Second Session, U.N. Doc. FCCC/SBI/1996/9, para. 66(c)(describing the treatment of the mutual fund under the convention). 